"Trade Shocks and Macroeconomic Fluctuations in Africa"

M. Ayhan Kose and Raymond Riezman

CSGR Working Paper No. 43/99

October 1999
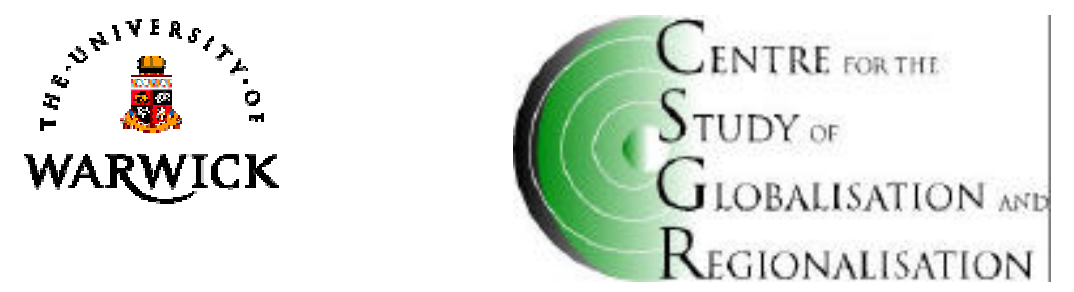


\title{
Trade Shocks and Macroeconomic Fluctuations in Africa
}

M. Ayhan Kose ${ }^{a}$ and Raymond Riezman ${ }^{1}$

Graduate School of International Economics and Finance, Brandeis University;

Department of Economics, University of Iowa.

CSGR Working Paper No. 43/99

October 1999

\begin{abstract}
:
This paper examines the role of external shocks in explaining macroeconomic fluctuations in African countries. We construct a quantitative, stochastic, dynamic, multi-sector equilibrium model of a small open economy calibrated to represent a typical African economy. In our framework, external shocks consist of trade shocks, modeled as fluctuations in the prices of exported primary commodities, imported capital goods and intermediate inputs, and a financial shock, modeled as fluctuations in the world real interest rate. Our results indicate that while trade shocks account for roughly 45 percent of economic fluctuations in aggregate output, financial shocks play only a minor role. We also find that adverse trade shocks induce prolonged recessions.
\end{abstract}

Keywords: Trade shocks, dynamic stochastic quantitative trade model, African economies. JEL Classification: F41, E31, E32, D58, F11.

Address for correspondence:

Ray Riezman,

Department of Economics,

University of Iowa,

Iowa City, IA 52242,

USA

e-mail: raymond-riezman@uiowa.edu

\footnotetext{
${ }^{\mathrm{a}}$ Graduate School of International Economics and Finance, Brandeis University, Waltham, MA 02254, e-mail: akose@lemberg.brandeis.edu.

${ }^{1}$ We are grateful to Simon Evenett, Jan Gunning, David Richardson, and Linda Tesar for their helpful comments. We also benefited from the suggestions of Ahmed El-Softy, Kamil Yilmaz, and seminar participants at the 1998 Fall Midwest International Economics Conference at the University of Michigan. The usual disclaimer applies.
} 


\section{Introduction}

There is a large and expanding literature suggesting that highly unstable domestic macroeconomic environment is one of the primary reasons for the poor growth performance of African countries in the last thirty years. ${ }^{1}$ The implication is that to improve growth performance in Africa, we need to understand why their economies are so volatile. That is the objective of this paper: using a dynamic, stochastic model we establish a link between external shocks and the highly volatile macroeconomic fluctuations in these economies. We investigate the effects of trade and financial shocks. Surprisingly, we find that, despite the fact that these countries are typically heavily indebted, trade shocks play a much more important role than financial shocks. In particular, it turns out that trade shocks explain almost half of the volatility in aggregate output.

International trade can induce macroeconomic fluctuations in a small open economy by two channels: one channel is through trade in goods and services, and the other one is by trade in financial assets. In African economies, these two channels have distinctively important roles in shaping domestic economic activity: first, the volume of international trade on average accounts for more than half of the aggregate output in these countries. Moreover, a narrow range of primary commodities constitutes a significant fraction of their exports, and their main import items are intermediate inputs and capital goods. Their export revenues are highly unstable due to recurrent and sharp fluctuations in the prices of primary commodities. Second, most of the African countries are heavily indebted, and a significant fraction of their export revenues are used to meet their debt service obligations. These make African countries extremely vulnerable to changes in the world interest rate.

A thorough understanding of the sources of macroeconomic fluctuations in African economies requires a good grasp of the impact of external shocks, namely fluctuations in the prices of exported primary commodities, imported capital goods, and intermediate inputs, and financial shocks, namely fluctuations in the world real interest rate, on domestic economic activity. In this paper, our objective is to shed some light on these issues by addressing the following questions: first, do trade disturbances account for a significant fraction of macroeconomic fluctuations? Second, how are trade shocks transmitted and propagated through these economies?

We begin by documenting some of the salient features of the economic structure, macroeconomic fluctuations, and dynamics of trade shocks to provide empirical evidence that there is a strong link between international trade disturbances and domestic economic activity in African countries. We, then, construct a multi-sector, dynamic, stochastic small open economy model which reflects the structural characteristics of a "representative" African economy. There are two sectors in the model: primary goods and nontraded final goods sectors. The economy exports primary goods, and imports all of its intermediate inputs and a significant fraction of its capital goods. The households in this economy can buy and sell one-period risk free bonds in the world financial markets. We also study the role of domestic factors in generating macroeconomic fluctuations as these factors are captured by the changes in productivity of the two sectors.

\footnotetext{
${ }^{1}$ Hadjimichael, Ghura, Muhleisen, Nord, and Ucer (1994), Sachs and Warner (1996), Ghura and Hadjimichael (1996), and Rodrik (1998a) use a variety of growth regressions to explain the determinants of economic performance and conclude that macroeconomic stability is an important factor for the long-run growth, Easterly and Levine (1997) emphasize the adverse impact of ethnic fragmentation on growth in African countries. In a recent paper, Collier and Gunning (1998) provide a detailed survey of this literature. Pindyck (1991), and Aizenman and Marion (1993) provide theoretical models where volatile macroeconomic environment
} 
We compare the properties of the macroeconomic fluctuations generated by this model with those actually observed in African countries. The results of this comparison suggest that the model successfully replicates some of the salient features of macroeconomic fluctuations in African economies.

We quantitatively evaluate the contribution of international trade shocks to domestic macroeconomic fluctuations. Our findings indicate that trade shocks play an important role in driving economic activity in African countries: almost 45 percent of fluctuations in aggregate output, is explained by world price shocks. Further, trade shocks account for almost 87 percent of aggregate investment variation. These results are consistent with those of Deaton and Miller (1996) who analyze the importance of international commodity prices in driving economic fluctuations in African countries using vector autoregression analysis. Their results suggest that while a sudden 10 percent increase in commodity prices results in a 6 percent increase in output, the price shocks most heavily affect investment dynamics in African economies. Another interesting outcome of our analysis is that world interest rate fluctuations do not have a significant impact on economic dynamics of African countries.

Impulse response analysis demonstrates that the propagation of economic fluctuations generated by the trade shocks is different than that caused by domestic productivity shocks. First, productivity shocks induce movements in the marginal product of factors of production. In contrast, trade fluctuations exhibit a rather indirect impact: shocks to the relative prices of imported capital goods, for example, result in substitution effects which trigger labor supply movements between the two sectors. Second, while positive productivity disturbances result in short lived expansions, adverse trade shocks cause prolonged recessions.

There has been a growing research program examining the link between domestic economic activity and trade shocks. ${ }^{2}$ While contributing to this literature, our paper is also related to some recent studies examining the sources of macroeconomic fluctuations in African countries: Deaton and Miller (1996) employ a VAR, and Hoffmaister, Roldos, and Wickham (1998) estimate a structural VAR model, where identifying restrictions are derived from a long-run small open economy model. While the former study concludes that trade shocks play an important role in driving macroeconomic fluctuations in these economies, the latter one finds trade disturbances account for only a small fraction of the variation in output.

This study extends the scope of this research program in several dimensions: first, we study the sources of macroeconomic fluctuations in African countries in a fully specified stochastic dynamic open economy model reflecting the structural characteristics of these economies. ${ }^{3}$ Since the model economy is dynamic, and involves endogenous labor-leisure choice, we are able to examine the link between trade shocks and fluctuations in aggregate investment, foreign asset holdings, and labor markets. The model economy employs domestically produced capital goods, imported capital goods, and imported intermediate inputs in two different sectors. This structure of differentiation in productive factors allows us to study the

\footnotetext{
has an adverse impact on growth. Ramey and Ramey (1995), using the data of developing and developed economies, find that countries with highly volatile macroeconomic environment have relatively lower growth.

2 Balassa (1978), Moran (1983), Feder (1983), and Basu and McLeod (1992) examine the relation between export instability and economic growth. See also Bevan, Collier, and Gunning (1993), Easterly, Kremer, Pritchett, and Summers (1993), Ghosh and Ostry (1994), Gavin and Hausmann (1996) and Rodrik (1998b). Bevan, Collier, and Gunning (1994) provide a computable general equilibrium model of an open economy to examine the economic experiences of Kenya and Tanzania after the major trade shock in 1976.

${ }^{3}$ See Baxter (1995) and Backus, Kehoe and Kydland (1995) for surveys on dynamic general equilibrium models of open economies. Senhadji (1995), and Mendoza (1995) analyze the importance of terms of trade shocks, and Kose (1997a) examines the role of world price shocks in driving business cycles in developing economies using a stochastic dynamic business cycles models of small open developing economies.
} 
impact of different types of trade shocks on different sectors of the economy. Second, our study considers a broader definition of trade shocks as it focuses on the price changes of the main export and import items instead of terms of trade disturbances. This is motivated by our empirical examination which reveals the terms of trade is not able to fully reflect the movements in highly volatile relative prices of main export and import items of African countries. Moreover, while assessing the role of relative price shocks, we investigate the impact of world interest rate fluctuations on domestic economic activity as well. Third, we examine the data of a large group of African countries, and document several stylized features of macroeconomic fluctuations in these economies.

The organization of the paper is as follows: in section 2, we review the empirical regularities of African country data. Following this, we present the model. Model calibration is described in section 4. In section 5, we first assess the ability of the model in replicating business cycle dynamics of a representative developing country. Then, we quantitatively evaluate the importance of different types of shocks in generating macroeconomic fluctuations. The model dynamics are analyzed using impulse responses. Following this, the sensitivity of the results to changes in the structural parameters of the model is briefly investigated. We conclude with a brief summary and suggestions for future research in section 6. An appendix, containing information about the solution of the model, data sources, and detailed data tables, is also provided.

\section{Analysis of the data}

In this section, we first document some of the salient features related to economic structure of several African countries. Following this, we analyze the main regularities of macroeconomic fluctuations observed in these economies. Next, we examine the cyclical behavior of trade shocks and their comovement with aggregate output and the trade balance. Our analysis is based on the annual data of twenty-two non-oil exporting African countries for the 1970-1990 period. ${ }^{4}$

\subsection{Structural characteristics of the African economies}

We begin with an examination of the decomposition of aggregate output to provide a better understanding of the structural characteristics of the African economies. We present information about the expenditure shares of aggregate output and industrial structure in Table 1a. The G7 average of each magnitude is also provided for comparison purposes. The major difference between these two groups is the role played by international trade in domestic economic activity. In African (G7) countries, exports account for almost 31 (20) percent of total GDP while imports constitute more than 40 (18) percent of it. Strikingly, the volume of trade on average accounts for more than 71 percent of GDP in African countries while only 38 percent of total GDP is attributable to the trade volume in the G7 countries. As Table 1a indicates, African countries have relatively large trade deficits: the average trade deficit is around 10 percent of the GDP in the African economies in our sample.

The difference between the average consumption shares of the two groups is also noticeable: for African countries, the average share is around 70 percent that is 10 percent more than the G7 average.

\footnotetext{
${ }^{4}$ We examine the data of 22 non-oil exporting African countries. 18 of these countries are Sub-Saharan African, 4 of them are Arabic: Burundi, Cape Verde, Egypty, Gambia, Ghana, Guinea Buissea, Kenya, Liberia, Madagascar, Malawi, Mauritania, Mauritius, Morocco, Seychelles, Sierra Lione, Sudan, Swaziland, Tanzania, Tunisia, Zaire, Zambia, and Zimbabwe. Detailed information about the data sources and definitions is given in Appendix A2.
} 
Having noted all these differences, it is interesting to observe that the shares of government expenditure aggregate investment in GDP are quite similar in both groups.

Characteristics of African economies' industrial structures also make them highly vulnerable to trade shocks: they have relatively smaller industry and service sectors, and, consequently, the share of agricultural sector is considerably larger in these countries. To be more specific, agricultural goods on average account for 28 (4) percent of total GDP while industrial items constitute roughly 18 (30) percent of total domestic income in African (G7) countries.

We then study the decomposition of exports and imports to determine the relative importance of different commodity groups in the international trade. Table $1 \mathrm{~b}$ describes the structure of exports. As this table clearly illustrates, the African economies heavily depend on primary goods for their export revenues. The share of primary exports on average is 77 percent. Food products and metals constitute 47 percent and 20 percent of total exports respectively. Interestingly, the average share of capital good exports is less than 2 percent in total exports. ${ }^{5}$ If these countries export a variety of primary goods, then their dependency to primary commodities for their export revenues might not be seen as an important problem, since fluctuations in the prices of different types of primary commodities can offset each other and result in relatively stable export earnings. In order to examine the extent of diversification of exports at a more disaggregated level, we use two different criteria that are presented in the last two columns of Table 1b. With both measures, the African countries in our sample seem to be much more concentrated in their exports than the G7 countries do. First, we examine the number of commodities exported by the African economies: They export on average 54 different goods. This number is around 213 for the G7. Second, we use the Gini-Herschman coefficient to measure the concentration of exports. ${ }^{6}$ A higher value of this coefficient indicates a higher degree of export concentration. While the average coefficient of export concentration is more than 60 for the African countries, it is less than 10 for the G7.

Table 1c provides information about the decomposition of imports. Two points about this table are noteworthy: first, the main import items of these countries are capital goods and intermediate inputs. While the imports of intermediate inputs account for almost half of the total imports, the average share of capital good imports is approximately 28 percent. Second, the average share of agricultural goods is minor in total imports. Table $1 \mathrm{~b}$ and $1 \mathrm{c}$ together present an interesting picture: while the export structures of the G7 economies and African economies are quite different, their import structures are similar on some dimensions. For example, both the G7 and African countries rely on imported manufactured goods.

Movements in the cost of servicing external debt also seem to be an important source of macroeconomic fluctuations in several African countries, particularly highly indebted ones. ${ }^{7}$ As Table 2 indicates, the average ratio of external debt to GNP is around 89 percent and debt service to export ratio, which is a widely used measure of debt burden, is around 20 percent for the African economies in our sample. Notably, the ratio of short-term debt payments to the export revenues is on average 43 percent.

\footnotetext{
${ }^{5}$ A number of African economies have recently increased the share of the manufactured exports in their total exports. However, the share of the manufactured exports is still a minor fraction of the total exports.

${ }_{7}^{6}$ See Appendix A2 for more information about this coefficient.

${ }^{7}$ Greene (1989) examines the debt problem of African countries and emphasizes the adverse impact of increases in the world interest rate on this problem. Fosu (1996) finds that the debt burden of Sub-Saharan African countries has a strong adverse impact on the growth performance of these countries using regression estimates.
} 
We conclude this section with some broad observations. While there might be some differences in the economic performance of African countries, these countries are quite similar in their industrial, and international trade structure. A typical African economy gets the bulk of its export revenues from a narrow group of primary commodities, imports mainly capital goods and intermediate inputs, faces persistent trade deficits, and has to allocate a significant fraction of its export revenues to meet its short term debt obligations. A model designed to examine the sources of macroeconomic fluctuations in African economies should reflect these characteristics.

\subsection{Main regularities of macroeconomic fluctuations}

We document some of the regularities associated with the macroeconomic fluctuations in African economies in Table $3 .^{8}$ We also present detailed tables with country specific data in appendix B. This investigation serves two purposes: first, we get a better understanding of the magnitude of economic fluctuations in these economies. Second, we set up a group of benchmark statistics that are going to be used in evaluating the performance of our model economy. All properties of the data refer to moments of HodrickPrescott (HP(100)) filtered variables. ${ }^{9}$ We focus on the three main features of macroeconomic fluctuations: volatility, measured by standard deviation, comovement, measured by correlations, and persistence, measured by autocorrelations.

Table 3 presents the properties of economic fluctuations for main macroeconomic aggregates: among the components of aggregate output, manufacturing production is the most volatile one. This evidence compounded with the observations in the previous section implies that outputs of the production sectors, such as manufacturing, which heavily depend on imported capital goods and intermediate inputs, show more aggregate volatility than the ones, such as agriculture sector, which mainly use domestically produced inputs. The variation in consumption is greater than that in aggregate output, since our consumption series include durable consumption goods. Different countries use different methods to measure fluctuations in the labor market, so the variation of employment across countries does not display any regular pattern: it ranges from 2.70 percent to 17.58 percent with an average of 7.33 percent (see appendix B.) As expected, investment exhibits high cyclical volatility. Analysis of the disaggregated external trade data indicates that both exports and imports are highly volatile. On average, exports are less volatile than imports. The trade balance is the most volatile series. It is surprising to observe that the African countries in our sample exhibit very similar characteristics in their macroeconomic fluctuations: for example, in 16 out of 19 countries for which data is available, volatility of manufacturing output is greater than the one of service sector.

We briefly examine the persistence and comovement properties of aggregate variables. Manufacturing output is more persistent than the trade balance, imports, and aggregate output. Agricultural sector output is the least persistent series with an average autocorrelation coefficient of 0.15 . Except the trade balance, all macro aggregates are procyclical.

\footnotetext{
${ }^{8}$ In a recent paper, Agenor, McDermott, and Prasad (1998) document the main stylized features of macroeconomic fluctuations of 12 developing countries noting that this is the first step to build stochastic dynamic models to see if these models can reproduce these stylized facts. Our study is the first one documenting these types of stylized features for African economies, and constructing a model to examine the macroeconomic fluctuations in these countries.
} 


\subsection{Dynamics of Prices}

There has been a revival of interest to understand the dynamics of commodity prices, since a number of developing countries have faced a very sharp downtrend in the prices of their main export items over the last two decades. ${ }^{10}$ Since our ultimate objective is to evaluate the effects of trade shocks proxied by relative price fluctuations on macroeconomic dynamics of African economies, we briefly examine the cyclical features of price series and provide further empirical evidence about the relation between these series and macroeconomic fluctuations in these countries. We start with a visual inspection by presenting the plots of annual change for the prices of main export and import items of African countries in Figures 1a-1d (Construction of relative price series of capital goods and intermediate inputs are explained in the next paragraph.) These prices exhibit very high cyclical volatility. The year-to-year variations have become increasingly magnified since the early 1970s. Very short lived price booms have been generally followed by prolonged troughs (see Deaton and Laroque (1992).) Figure 1e describes the behavior of terms of trade of African countries. As these figures clearly demonstrate, while providing some information about recurrent fluctuations, the terms of trade is unable to reflect the sharp peaks and deep troughs observed in the prices of major export and import items (see Kouparitsas (1997b).)

Next, we look at the stylized facts pertaining to fluctuations in particular relative price series. Instead of analyzing the terms of trade dynamics only, we also examine a disaggregated measure of the terms of trade and look at the dynamics of relative prices of capital goods and intermediate inputs to primary goods. As we reported in Section 2.1., these three groups of commodities constitute a significant fraction of the trade volume in African countries. Table 4 documents our findings. The relative price of capital goods to primary goods, $p_{t}^{k}$, is calculated as the ratio of the U.S. producer price index of capital equipment to the export price index of the domestic economy. The relative price of intermediate goods, $p_{t}^{v}$, is equal to the ratio of the U.S. producer price index of intermediate materials to the export price index of the domestic economy. ${ }^{11}$ The terms of trade is calculated as the ratio of export price index to import price index of each country.

Interestingly, the relative prices are more volatile and more persistent than the terms of trade. The relative prices of capital goods (intermediate inputs) to primary commodities are 1.23 (1.11) times more volatile than the terms of trade. The persistence of the terms of trade is 0.22 while the persistence of relative price of capital (intermediate) goods is 0.38 (0.35.) Combined with our earlier observations these findings imply that models, in which the terms of trade fluctuations are the only external driving shock, might potentially underestimate the role of relative prices in inducing macroeconomic fluctuations, since the terms of trade series alone are unable to reflect the dynamics of disaggregated prices and the interactions between these prices and aggregate output. ${ }^{12}$

\footnotetext{
${ }^{9}$ To find the trend path of the time series, this method solves a constrained optimization problem that involves minimizing the sum of squared deviations from the time series subject to the constraint that the sum of squared second differences not be too large. See Hodrick and Prescott (1997) for more information about this filter.

${ }^{10}$ Reinhart and Wickham (1994) find that there has been a steady and considerable increase in the volatility of commodity prices since the early 1970s. See also Ghosh and Ostry (1994), who examine the optimal policy response of a typical developing country to fluctuations in its export earnings.

${ }^{11} \mathrm{We}$ also calculated some other relative price measures using export and import price indices of some other industrialized countries. Our empirical observations were not changed, when we used different price series.

${ }^{12}$ Kouparitsas (1997b) provides extensive evidence that the relative prices are more volatile than the terms of trade. Although he is using a different data set, his results are very close to ours: he finds that the relative prices of non-fuel commodities to manufactured
} 
There is a vast empirical literature on the world interest rate fluctuations and implications of these fluctuations on macroeconomic activity. ${ }^{13}$ Figure $1 \mathrm{f}$ plots the annual change of the world real interest rate over twenty-five years. Our world real interest rate measure is the six-month LIBOR (the London Interbank Offer Rate) deflated by changes in export unit value index of non-fuel commodity exporting developing countries. As this figure indicates, there has been a substantial increase in the world real interest rate since the beginning of the 1980s. Over the years of 1974-1979, the average real cost of borrowing for developing economies decreased by 16.8 percent. Following this, the cost increased by 5.9 percent between 1980 and 1993. The sudden rise in the world interest rate in 1981 dramatically increased the burden of debt service for several highly indebted developing economies and marked the beginning of the debt crisis.

\section{The Model Economy}

In the previous section, we provided substantial empirical evidence suggesting that the economies of African countries exhibit a number of common structural features. In this section, we construct a multi-sector dynamic stochastic small open economy model that reflects the main structural features of a typical African economy.

\subsection{Preferences}

The economy is inhabited by a large number of infinitely lived, identical households who do not have any control over the prices of its exports and imports, and the world real interest rate. The representative household maximizes expected lifetime utility given by

$$
\begin{aligned}
& U(c, l)=E_{0}\left\{\sum_{t=0}^{\infty} \beta^{t} \frac{\left[u\left(c_{t}, l_{t}\right)-1\right]}{1-\sigma}\right\} \\
& \sigma>0, \beta>0
\end{aligned}
$$

where the parameter $\beta$ denotes the subjective discount factor of the household and $\sigma$ is the risk aversion parameter. $c_{t}$ is the consumption of the non-traded final good, $l_{t}$ represents leisure.

Neither exported nor imported goods are modeled as utility deriving goods in the model because of the following reasons: first, the empirical evidence provided in the previous section indicates that a significant fraction of exports is coming from the primary goods sector in African countries. These exported primary goods are generally used as inputs in producing final goods, so the contribution of these goods to utility is via final goods. Second, recent empirical studies indicate that consumer goods have a minor share in the total imports of developing countries. ${ }^{14}$

The instantaneous utility function $\mathrm{u}$ has the form

goods is 1.37 times more volatile than the terms of trade. Kouparitsas also shows that terms of trade can be written as a linear function of relative prices.

${ }^{13}$ See Sachs (1989, pages 7-8) for an extensive discussion about "the role of global shocks" and, in particular, the importance of world interest rate fluctuations as an inducing factor of the debt crisis. Ozler and Rodrik (1992), through cross-country regressions, find that the world real interest rate fluctuations have a significantly negative impact on private investment in developing countries.

${ }^{14}$ Hentschel (1992, page 8) analyzes the composition of imports for several developing countries, and concludes "a general characterization of the imports as consumption goods is not justified." 


$$
u\left(c_{t}, l_{t}\right)=\left(c_{t}-\psi\left(1-l_{t}\right)^{v}\right)^{1-\sigma} \quad v>1, \psi>0
$$

This utility function implies the marginal rate of substitution between consumption and leisure is a function of the leisure only, so labor effort does not depend on the intertemporal consumption-saving choice.

\subsection{Technology}

The economy produces nontraded final goods and primary goods. Nontraded final goods production, $y_{t}^{f}$, uses labor, $n_{t}^{f}$, capital, $k_{t}^{f}$, and intermediate inputs, $v_{t}$ :

$$
\begin{gathered}
y_{t}^{f}=z_{t}^{f}\left(n_{t}^{f}\right)^{\alpha}\left[s\left(k_{t}^{f}\right)^{-u}+(1-s) v_{t}^{-u}\right]^{-(1-\alpha) / u} \\
0<\alpha, s, u<1
\end{gathered}
$$

$z_{t}^{f}$ represents the exogenous productivity shock. $\alpha$ is the share of non-traded output earned by labor and $\mathrm{s}$ is the relative weight of capital. The elasticity of substitution between intermediate inputs and capital is governed by $u$. The empirical evidence presented in the previous section suggests that the cost of intermediate inputs constitutes a substantial fraction of the total factor cost. The CES formulation allows us to analyze the impact of degree of substitutability between domestic capital goods and foreign intermediate inputs on the dynamics of our model.

The primary goods sector produces output by using labor, $n_{t}^{p}$, capital, $k_{t}^{p}$, and land, $L^{p}$ which is assumed to be inelastically supplied. The production function in the primary goods sector is given as

$$
\begin{gathered}
y_{t}^{p}=z_{t}^{p}\left(n_{t}^{p}\right)^{\theta_{1}}\left(k_{t}^{p}\right)^{\theta_{2}}\left(L^{p}\right)^{1-\theta_{1}-\theta_{2}} \\
0<\theta_{1}, \theta_{2}<1
\end{gathered}
$$

where $z_{t}^{p}$ is the technology shock. $\theta_{1}$ and $\theta_{2}$ are the labor and capital income shares respectively.

Capital accumulation is modeled as

$$
k_{t+1}^{j}=(1-\delta) k_{t}^{j}+\phi_{j}\left(\frac{i_{t}^{j}}{k_{t}^{j}}\right) k_{t}^{j} \quad j=f, p
$$

Here $\delta$ is the rate of depreciation, $i_{t}^{j}$ is the amount of investment in sector $\mathrm{j}$, and $\phi_{j}($.$) represents the concave$ adjustment cost function, with $\phi_{j}()>0,. \phi_{j}(.)^{\prime}>0$, and $\phi_{j}(.)^{\prime \prime}>0$. The adjustment cost prevents frequent movements of capital across sectors and excessive volatility of investment.

We assume that primary sector capital is imported and capital used in the non-traded goods sector is domestically produced. This way of modeling capital is empirically appealing since capital goods used in primary goods sector are generally machinery and equipment items, and a significant fraction of capital goods used in the non-traded final goods sector can be classified as intermediate inputs, such as construction materials and energy.

\subsection{Financial Markets}

Each household has free access to world financial markets. However, these markets are incomplete in the sense that the household can trade a single financial asset, $A_{t}$, with a rate of return, $r_{t}$, from period to 
t+1. Kose (1997b) provides empirical evidence about the limited access of households in developing countries to international financial markets. The holdings of financial assets evolve according to the formula

$$
A_{t+1}=n x_{t}+A_{t}\left(1+r_{t}\right)
$$

where $n x_{t}$ represents the balance of trade. The household can partially smooth its consumption stream by borrowing and lending in the international financial markets. The possibility of the agent playing a Ponzi game and accumulating an infinite amount of debt is ruled out by imposing the condition:

$$
\lim _{t \rightarrow \infty} E_{0}\left(A_{t} \frac{1}{\left(1+r_{t}\right)^{t}}\right)=0
$$

In addition to this, we assume that $\beta=1 /\left(1+r^{*}\right), r^{*}$ is the steady state level of interest rate. It is known that when the discount rate is smaller (greater) than the interest rate, the representative household accumulates (decumulates) assets in a deterministic version of the model. In other words, there is no steady state equilibrium in those cases. If the two are equal, the economy is at a steady state equilibrium which is compatible with any level of foreign asset holdings. ${ }^{15}$

\subsection{Resource constraints}

The resource constraint for the nontraded goods sector is given by

$$
c_{t}+i_{t}^{f}=y_{t}^{f}
$$

and for the primary goods sector is

$$
p_{t}^{k} i_{t}^{p}+p_{t}^{v} v_{t}+n x_{t}=y_{t}^{p}
$$

where $i_{t}^{f}$ and $i_{t}^{p}$ are investment in capital goods in the nontraded and primary goods sectors respectively. $p_{t}^{k}$ and $p_{t}^{v}$ denote the relative prices of capital goods and intermediate inputs to primary goods respectively. The price of the primary good is numeraire.

The household, who has a fixed time endowment normalized to one, faces the following laborleisure allocation constraint

$$
l_{t}+n_{t}^{f}+n_{t}^{p}=1
$$

While labor input is assumed to be mobile across the sectors, it is not internationally mobile.

\footnotetext{
${ }^{15}$ Since models of small open economies with time separable preferences do not accept a "stable" steady state, some researchers use models with stationary cardinal utility (Mendoza (1995)), or models with finitely lived agents (Finn (1990)), or models with an exogenously imposed supply function for asset holdings (Senhadji (1995)) to get "well-defined" steady state dynamics and to have a realistic match between the data and the model outcome. Our formulation is similar to Correia, Neves and Rebelo (1995), Rebelo and Vegh (1995), and Ahearne (1997). We assume that the discount factor is equal to the interest rate at the steady state of the model, since our analysis is limited to dynamics at business cycle frequencies around the steady state of the model. Since this formulation results in an "equilibrium" which depends on the initial conditions imposed by the researcher, determination of those conditions might affect the results. This might be a serious problem if the researcher investigates the impact of a particular policy and its implications associated with the low frequency dynamics of the model variables. However, in models such as ours, dynamics at business cycle frequencies around the steady state of the model are analyzed.
} 


\subsection{Exogenous shocks}

There are five shocks in the model: two shocks to the relative prices of imported capital and intermediate goods, a world interest rate shock, and two sectoral productivity shocks. The vector of exogenous shocks is represented by $Z_{t}=\left[p_{t}^{k}, p_{t}^{v}, r_{t}, z_{t}^{f}, z_{t}^{p}\right]^{\prime}$. The evolution of $Z_{t}$ follows a first order Markov process and is given by

$$
\ln Z_{t+1}=\Pi \ln Z_{t}+\varepsilon_{t+1}
$$

The vector of innovations is denoted by $\varepsilon_{t}=\left[\varepsilon_{t}^{k}, \varepsilon_{t}^{v}, \varepsilon_{t}^{r}, \varepsilon_{t}^{f}, \varepsilon_{t}^{p},\right]^{\prime}$ where $\varepsilon_{t} \sim N(0, \Sigma)$.

\subsection{Numerical Solution Method}

The model economy is solved using the optimization problem of the representative household. This corresponds to a stochastic dynamic optimization problem which is solved by maximizing the expected lifetime utility, (1), subject to the constraints (3)-(10). Since this problem cannot be solved analytically, we find an approximate solution by using log-linear functions of the model variables. We describe the optimization problem and our solution method in Appendix A1. The solution method we use, namely the log-linear approximation method, was shown to be quite accurate in solving stochastic dynamic general equilibrium models. ${ }^{16}$

\section{Model Calibration}

Model calibration amounts to selecting a combination of parameter values that are roughly consistent with the long-run features of the economic environment of a representative African economy. The parameters and business cycle statistics of this representative economy correspond to the averages of relevant variables of the African countries in our sample and presented in Table $5 .^{17}$

\subsection{Preferences}

The risk aversion parameter, $\sigma$, is assumed to be 2.61 which is the GMM estimate from the panel study of a group of developing economies by Ostry and Reinhart (1992). The intertemporal elasticity of substitution in labor supply, $1 /(\mathrm{v}-1)$, is equal to 0.83 . Prior empirical studies show that the value of this parameter is between 0.3 and 3.2 (see Greenwood, Hercowitz and Huffman (1988)). The value of $\psi$ is selected so that the fraction of hours worked in the steady state is consistent with our assumption about the allocation of labor hours between the market and non-market activities.

As the world real interest rate measure, we use the LIBOR (the London Interbank Offer Rate) deflated by changes in export unit value index of non-fuel commodity exporting developing countries. The average world real interest rate, $r^{*}$, is found to be 2.9 percent annually. Since the interest rate is equal the discount rate at the deterministic steady state, the discount factor, $\beta$, is equal to 0.97 .

\footnotetext{
${ }^{16}$ See Ingram (1995) for a brief explanation of this method and several other issues related to the solution and estimation of stochastic dynamic general equilibrium models. The method of log-linear approximation was popularized by King, Plosser and Rebelo (1988).

${ }^{17}$ We are unable to provide estimates for the parameters of the model by employing formal econometric techniques, such as generalized method of moments (GMM), since our sample does not have enough observations to utilize such techniques. Instead, we base our calibration on the estimates provided by earlier econometric studies.
} 


\subsection{Technology}

The labor share for the nontraded final goods sector, $\alpha$, is assumed to be 0.45 . We choose a value of 0.58 for the Allen elasticity of substitution between capital and intermediate goods. This value is consistent with the estimates provided by Berndt and Wood (1975). ${ }^{18}$

The relative weight of capital, $\mathrm{s}$, is set at 0.55 . At the steady state, the capital goods and intermediate inputs shares are equal to 0.23 and 0.32 respectively. We assume that the share of labor, $\theta_{1}$, is 0.37 . By using sectoral data and the first order condition for primary capital, we find that the share of land, $1-\theta_{1}-\theta_{2}$, is equal to 0.45 . We select the rate of depreciation at 0.10 that is a widely used value in the business cycle literature.

It is enough to specify the three parameters, which describe the cost of adjustment functions in the two sectors, to analyze the near steady state dynamics of the model. Following Baxter and Crucini (1993), we assume that $\phi\left(i_{f} / k_{f}\right)=\phi\left(i_{p} / k_{p}\right)=\delta$ and $\phi^{\prime}\left(i_{f} / k_{f}\right)=\phi^{\prime}\left(i_{p} / k_{p}\right)=1$ at the steady state. This specification implies that there are no adjustment costs at the steady state of the model, and capital to its replacement cost, Tobin's "Q", is equal to 1 . The elasticity of the marginal adjustment cost function, $\eta=-\left(\phi^{\prime} / \phi^{\prime \prime}\right) /(i / k)$, for each type of capital is fixed, so that the volatility of investment generated by the model is equal to the one in the data. Trade balance to aggregate output ratio is equal to the average one in the data $(-0.096$.)

\subsection{Exogenous shocks}

\subsubsection{Productivity Shocks}

We estimate the total factor productivity in the nontraded goods sector, $z_{t}^{f}$, using the formula of the Solow residual in logarithms

$$
\log \left(z_{t}^{f}\right)=\log \left(y_{t}^{f}\right)-\alpha \log \left(n_{t}^{f}\right)
$$

$y_{t}^{f}$ is the total real value added of industry and service output. $n_{t}^{f}$ is equal to the employment index since data on labor hours is unavailable for most of the countries in our sample. The capital stock and intermediate input usage are excluded from the formula due to the following reasons: first, it is known that fluctuations in the capital stock are not large in the short-run. Second, the contemporaneous correlation between the capital stock and output is negligible. Third, the data on intermediate input usage is not available. We fit an univariate $\mathrm{AR}(1)$ process to find the parameters of the productivity shock for each country and then take an average over the whole sample of these parameters. These averages are assumed to be the relevant parameters for the representative developing economy. By following the same steps and using the data of agricultural value added, and employment in manufacturing sector, we estimate the shock process for the primary sector output.

\subsubsection{Exogenous Shocks}

We determine the parameters of the processes of exogenous shocks by using an univariate AR(1) processes. ${ }^{19}$ We do not have world price indices that are specifically designed for capital goods and

\footnotetext{
${ }^{18}$ The value of $u$, which governs the elasticity of substitution between capital and intermediate goods, is calculated by using the formula $u=\frac{1-\left(\alpha+\sigma_{k, v}-\alpha \sigma_{k, v}\right)}{\alpha+\sigma_{k, v}-\alpha \sigma_{k, v}}$ where $\sigma_{k, v}$ is the Allen elasticity of substitution (see Sato (1967)). The elasticity of substitution between the intermediate inputs and capital goods is equal to $1 /(1+u)$.
} 
intermediate inputs. However, this type of data is available at the country level. We conjecture that world prices of those goods closely follow the prices of the same goods produced in the U.S. So, the U.S. producer price indices of capital equipment and intermediate goods are used to represent the prices of imported capital and intermediate goods respectively. The price series of primary commodities correspond to the export unit values of each country. This assumption is easily justified because a significant portion of African country exports come from primary commodities. The relative price of capital goods (intermediate inputs) to primary commodities is the ratio of the U.S. producer price index of capital equipment (intermediate inputs) to the export unit value index for each economy. In order to estimate the world real interest rate, we use the sixmonth LIBOR (the London Interbank Offer Rate) deflated by changes in export unit value index of non-fuel commodity exporting developing countries. ${ }^{20}$

We find the variance-covariance matrix of innovations by using the covariances between the residual terms of estimated processes for each country. Then, we take the average of these matrices over the sample. The resulting specification for exogenous processes is given by

$$
\begin{gathered}
\Pi=\left[\begin{array}{ccccc}
0.44 & 0 & 0 & 0 & 0 \\
0 & 0.42 & 0 & 0 & 0 \\
0 & 0 & 0.34 & 0 & 0 \\
0 & 0 & 0 & 0.54 & 0 \\
0 & 0 & 0 & 0 & 0.32
\end{array}\right] \\
\Sigma=\left[\begin{array}{cccccc}
0.22^{2} & \mathbf{0 . 7 1} & \mathbf{0 . 3 5} & -\mathbf{0 . 1 9} & -\mathbf{0 . 0 1} \\
0.18^{2} & 0.21^{2} & \mathbf{0 . 2 9} & -\mathbf{0 . 3 0} & -\mathbf{0 . 0 5} \\
0.11^{2} & 0.10^{2} & 0.17^{2} & -\mathbf{0 . 0 5} & -\mathbf{0 . 0 3} \\
-(0.04)^{2} & -(0.04)^{2} & -(0.02)^{2} & 0.03^{2} & \mathbf{0 . 0 6} \\
-(0.01)^{2} & -(0.02)^{2} & -(0.01)^{2} & 0.08^{2} & 0.04^{2}
\end{array}\right]
\end{gathered}
$$

The bold values in $\Sigma$ represent the correlations between the innovations.

\section{Results of the simulations}

This section starts with an evaluation of our model's ability in terms of capturing main regularities associated with macroeconomic fluctuations in a typical African economy. Then, we examine the importance of different types of shocks in generating macroeconomic fluctuations employing variance decompositions. Next, the propagation mechanisms of exogenous shocks in the model economy are analyzed using impulse responses. Following this, we provide a brief discussion about the sensitivity of our results to changes in the deep parameters of the model.

\footnotetext{
${ }^{19}$ See Deaton and Miller (1996) for a similar AR(1) modeling of price series.

20 The LIBOR is used as a benchmark interest rate measure by international organizations and commercial banks when they give loans to developing countries. See World Economic Outlook (1993, p. 83) for the use of this measure as a proxy for real cost of borrowing for developing economies.
} 


\subsection{How successful is the model?}

While it is not our primary objective to examine the ability of our model in terms of matching the main characteristics of macroeconomic fluctuations in African economies, we still think that this is an useful exercise since our model economy is the first one in its class designed to study economic dynamics of African countries. The theoretical model is simulated with the specification described in the previous section. The moments of actual data refer to those moments calculated for the representative African country and are presented in Table 6. Our focus is on the predictions of the model related to volatilities of main macroeconomic aggregates and their contemporaneous correlations with aggregate output. Table 7 summarizes our findings about the sample second order moments of the model variables. Each statistic is the sample average of across 1000 simulations of the same length as the data (23 years). The simulated data is also detrended with the HP(100) filter to make the results comparable to the data analysis in section 2.

In terms of matching volatility properties of macro aggregates, the model is quite successful. Qualitatively, it replicates most of the features of actual data: both trade balance and investment are more volatile than aggregate output. The model also captures the volatility ordering of outputs of production sectors: the primary sector output has the largest variability, and aggregate output is the least volatile series. From a quantitative perspective, the model is able to reproduce some of the stylized facts. For example, it is able to mimic volatilities of sectoral outputs and aggregate output with a small margin. The predicted standard deviation of the trade balance is slightly higher than the actual one. We set the relevant elasticities of adjustment cost so the model can exactly replicate the volatility of investment.

The volatilities of consumption and employment relative to output are seemingly low in the model economy. This is not a surprising result and should not be interpreted as a weakness of the model: first, the only available data on consumption in African countries, which we have access to, includes both non-durable and durable consumption expenditures. Unlike the data, our model does not take into account durability. Hence, a direct comparison of the model generated consumption data with the actual one might result in an inaccurate assessment of the model. It is known that the volatility of durable goods consumption is two to four times higher than that of non-durable consumption. ${ }^{21}$ Second, the labor supply variation in the model is captured only along the intensive margin. Conversely, we have employment data which measures the labor supply fluctuations only along the extensive margin. Earlier empirical studies indicate that the volatility of employment is two to three times higher than that of labor hours. Interestingly, the prediction of the model concerning employment fluctuations is also consistent with this empirical regularity: the volatility of labor hours in the model is approximately three times as low as the one of employment series in the data.

We next evaluate the performance of the model in replicating comovement properties of the data. While quite closely matching the correlation between the primary sector output and aggregate output, the model overpredicts the aggregate output-final sector output correlation. The correlations between consumption and output, and between investment and output in the model are higher than those in the data. ${ }^{22}$ The output-labor hours correlation in the model is higher than the output-employment correlation in the data.

\footnotetext{
${ }^{21}$ See Backus, Kehoe and Kydland (1995) for a similar argument about the volatility of durable goods consumption. Baxter (1996) provides an extensive discussion about the durables vs. nondurables goods differentiation and its macroeconomic implications.

${ }^{22}$ In our model, the representative household cannot intratemporally substitute consumption goods in response to the relative price fluctuations, since she derives utility by consuming only nontraded goods. It is possible to remedy near perfect procyclical behavior of consumption by allowing the household to consume a variety of goods, such as exportable and importable goods. This results in
} 
This is also an expected result since the form of the utility function implies that the number of hours worked at time $t$ is determined by aggregate output. One of the important features of the model economy is its ability to generate countercyclical behavior of the trade balance series. Interestingly, compared with the actual data, there is a relatively high negative correlation between the trade balance and aggregate output in the model. This result might be due to the presence of trade shocks which are negatively correlated with sectoral productivity shocks in the model. We further investigate this possibility in section 5.4.

\subsection{How important are the trade shocks?}

Our main objective is to determine the relative contribution of the trade shocks to macroeconomic fluctuations in African economies. We apply the variance decomposition method on the solution of the model to determine the relative importance of shocks in explaining economic variations. In other words, we decompose the variances of macroeconomic variables into fractions explained by exogenous shocks. This method requires us to impose a certain information ordering on the shocks because the relative contribution of each disturbance to macroeconomic fluctuations is sensitive to its place in the shock specification. Since our model represents a small open economy, there is a natural ordering of shocks. By construction, the small open economy does not have any control over the external shocks it faces in the world markets. This implies that domestic shocks do not have any impact on the external shocks, i.e. the external shocks precede sectoral productivity shocks in our specification. ${ }^{23}$

The results of the variance decompositions, which are obtained by using the information ordering in (10), are reported in Table 8. The first three columns present the fraction of variance due to trade shocks. Strikingly, a significant fraction of macroeconomic fluctuations is explained by trade shocks. They account for more than 44 percent of the variation in aggregate output. Our results indicate that shocks to the relative price of capital goods to primary goods play a more important role than shocks to the relative price of intermediate inputs. While almost 25 percent of variability in aggregate output is due to the changes in relative prices of capital goods, less than 20 percent of the fluctuations is due to the disturbances to relative prices of intermediate inputs. The domestic productivity disturbances play an important role in driving economic activity: roughly 55 percent of the output variation is due to productivity disturbances. Interestingly, most of the variation explained by the productivity shocks is due to the domestic productivity movements in the final goods sector.

In our model, trade shocks have a direct impact on output fluctuations, since both sectors of the economy use imported goods as factors of production. A significant fraction of the macroeconomic volatility in the final goods producing sector, that heavily relies on imported intermediate inputs and domestic capital goods, is explained by the trade shocks. Roughly 46 percent of the output variation in the nontraded final goods producing sector is due to the trade shocks. Interestingly, trade disturbances play a more important role in explaining consumption fluctuations than they do in output variation: almost 80 percent of the variation in consumption is due to the trade shocks.

Our results also show that trade shocks have a large impact on macroeconomic fluctuations in production factors: more than 86 percent of the volatility of aggregate investment is explained by trade disturbances. In particular, shocks to the relative prices of primary capital goods account for more than 98

pronounced consumption substitution effects in response to the relative price fluctuations and decreases the correlation between aggregate output and consumption. 
percent of the variation in primary investment. This result can be explained by the fact that all investment goods in the primary good producing sector are imported capital goods. More than 42 percent of the variation in intermediate inputs is explained by the disturbances to the relative prices of intermediate goods.

Shocks to the prices of capital goods and intermediate inputs also play an important role in inducing fluctuations in the labor market. Movements in the relative prices of capital goods (intermediate inputs) account for more than 42 (37) percent of the variation in the total labor hours. Domestic productivity shocks explain a larger fraction of the variation in the primary goods sector than the final goods sector.

Trade balance dynamics and foreign asset holdings are also heavily affected by the price fluctuations in the world markets. This is an intuitively appealing result: in section 2 we report that exports, imports, and trade balance series are extremely volatile in African economies. Then, we constructed a model to represent a typical African country where the households export all the primary goods they produce while importing intermediate inputs and capital goods. Now, we establish the connection between highly volatile price shocks and trade balance dynamics: almost 74 percent of the fluctuations in the trade balance is accounted for by the trade shocks. Shocks to the relative prices of capital goods explain more than 45 percent of the volatility in the foreign asset holdings.

These results are consistent with those of Deaton and Miller (1996) who analyze the importance of international commodity prices in driving economic fluctuations in African countries using vector autoregression analysis. Their results suggest that while a sudden 10 percent increase in commodity prices results in a 6 percent increase in output, the price shocks most heavily affect investment dynamics in African economies.

Interestingly, we find that world real interest rate shocks do not play a significant role in driving domestic economic activity in our model. For example, they account for less than 1 percent of the output volatility. As expected, these shocks have a relatively more important role in driving the dynamics of asset holdings, but their influence is still very small compared to the role of other shocks: less than 6 percent of the variation in foreign asset holdings is explained by interest rate disturbances.

Why does the world interest rate play such a minor role in driving economic fluctuations in African countries? First, world interest rate shocks do not have a direct impact on output fluctuations in our model: a rise in the world interest rate, for example, results in a shift of domestic savings to foreign assets and decreases investment in production. The change in investment affects the dynamics of output. On the other hand, relative price shocks have a relatively more direct effect on fluctuations in productive inputs and output, and play a relatively more important role in inducing macroeconomic fluctuations. Secondly, when we look at the data, we observe only a few large interest rate changes (see Figure 1f). Capturing the effects of those large and short lived interest rate fluctuations on economic activity requires the use of different techniques which allow a researcher to examine the relationship between macroeconomic fluctuations and world interest rate shocks over short time periods.

\subsection{The dynamic effects of shocks}

We study the dynamic effects of trade and productivity shocks by using impulse response analysis. This investigation provides information about the differences between the propagation mechanisms of productivity and trade disturbances. We analyze the impulse responses of model variables to a 1 percent

${ }^{23} \mathrm{We}$ also analyzed the sensitivity of these results to different orderings of the shocks. This investigation indicates different information orderings do not cause significant changes in the results reported here. 
temporary shock. The results, presented in Figures 2-4, are plotted as percentage deviations from the initial steady state.

We present the impulse responses of model variables to a temporary 1 percent increase in productivity of both sectors in Figure 2. A sudden increase in productivity results in an economy-wide boom: output increases in both sectors. This causes a rise in demand for imported capital goods, intermediate inputs and labor supply. Since the increase in exports (primary goods) is less than the rise in imports (the sum of the imported investment and intermediate goods), the economy has a substantial trade deficit. The representative household increases its consumption. Qualitatively, the sectoral productivity shocks lead to more pronounced effects in investment and trade balance compared to the those in output and consumption.

Figure 3 shows the time paths of model variables in response to a 1 percent temporary increase in the relative price of capital goods, which are used in the primary goods sector. This type of adverse price shock pushes the economy into a recession. Investment in primary goods sector sharply drops; however this decrease does not lead to a significant decline in aggregate investment since the share of primary investment in the aggregate investment is relatively small. The representative household momentarily increases its labor supply in the primary goods sector to compensate the fall in investment. The economy faces a major decline in its export revenues and has to deal with the problem of deteriorating trade balances. Aggregate production decreases due to a shortage of productive inputs. Consumption also goes down. These impulse response plots clearly show the typical transmission mechanisms of macroeconomic fluctuations in a number of African countries which are often subjected to relative price fluctuations: contraction in the exports sector, following a fall in the relative price of exports, causes a substantial decline in the imports of productive inputs which is followed by a decrease in consumption. The economy starts borrowing from world financial markets.

We present the impulse responses of the model variables to a 1 percent temporary increase in the relative price of intermediate inputs in Figure 4. The economy-wide impact of this shock is clearly more destructive than the one of the relative price of capital goods, since it hits the non-traded final good sector in a direct manner. Production in both sectors go down, the decrease in the primary goods production is much larger than that in the final goods production. The decrease in the relative price of exports reflects itself in the primary sector and production in this sector contracts almost 0.15 percent. Consequently, trade deficit gets larger. The contraction in production spreads to the demand for productive inputs: total investment and demand for intermediate inputs both go down. The household decreases its labor supply in both sectors. The trade balance deteriorates as households accumulate foreign debt.

Since labor supply in each sector is endogenously determined in our model, we can analyze the movements of labor across the two sectors. Our results suggest that the magnitudes of labor supply responses in the traded and non-traded sectors of a typical African economy, are comparable with those of the other variables when the model is subjected to domestic productivity and international trade shocks. For example, in response to a 1 percent temporary productivity shock in primary sector, there is a considerable increase in the labor supply in that sector, a decrease of labor supply in the non-traded goods sector, and an increase in the aggregate labor supply. Correspondingly, primary sector output increases and the production in nontraded final goods sector slightly decreases due to a shortage of productive inputs. ${ }^{24}$

\footnotetext{
${ }^{24}$ These results are in line with those findings by van Wincoop (1992) who argues that whether export sector expands or contracts in response to an exogenous shock depends on the labor supply movements between that sector and the other sectors of the economy in developing countries which face extremely volatile export prices.
} 
The overall effect of trade shocks in our model is the opposite of that of domestic productivity shocks since trade shocks act like negative productivity shocks. While positive productivity shocks stimulate the economy and result in short lived expansions, negative trade disturbances have adverse implications: they cause negative income effects which are accompanied by a fall in consumption, and a contraction in demand for productive inputs. Furthermore, trade shocks lead to prolonged recessions by having a detrimental impact on aggregate investment.

The impulse responses of a 1 percent temporary increase in world interest rate shock are not presented here because of the space considerations. This shock does not generate significant movements in the model variables except the trade balance and foreign asset holdings. An increase in the world interest rate decreases total domestic investment as the representative household starts accumulating foreign assets. She shifts more of its consumption to the future periods which results in a decrease in current consumption. Aggregate output falls while primary sector has a mild and short lived expansion. This in turn favors the trade balance and the economy increases its exports while decreasing the imports of productive inputs.

\subsection{Sensitivity Analysis}

In this section, we first analyze the individual roles of productivity and trade shocks in our model. In table 9, the results of a simulation when only trade shocks are present are reported. Lacking productivity shocks, the model is not able to match the volatilities of aggregate output and its components. The correlation between the trade balance and output is around -0.85 . This result is consistent with our earlier conjecture about the large negative correlation between the trade balance and aggregate output in our benchmark simulation: the presence of trade shocks which are negatively correlated with the productivity disturbances is responsible for relatively high negative correlation between output and the trade balance.

We then simulate the model with only productivity shocks. The results of this experiment are also given in Table 9. The model underpredicts the volatility of primary sector output. It matches neither the variation of aggregate output nor the one of final sector output. Further, the model does a very poor job in replicating consumption, investment and labor dynamics when the trade shocks are absent. This shows the importance of trade shocks in replicating regularities of macroeconomic fluctuations in a small open economy model designed for a representative African economy.

To further examine the role of the world interest rate fluctuations, we decrease the trade balance to aggregate output ratio. We decrease the trade deficit by 50 percent, from 9.6 percent to 14.4 percent. In this case, the world real interest rate shocks explain more than 11 (14) percent of the fluctuations in trade balance (asset holdings) while accounting for almost 2.5 percent of the aggregate economic volatility. This result implies that as trade deficit of our representative economy increases, its reliance to the world financial markets becomes deeper, and this makes the changes in the world interest rate more important in domestic economic fluctuations.

We investigate the sensitivity of our results to the changes in the structural parameters of model. We briefly discuss the results of this investigation for four parameters: the elasticity of substitution in intermediate and capital goods, the intertemporal elasticity of substitution in labor supply, the risk aversion parameter, and the elasticity of marginal adjustment cost. An increase in the elasticity of substitution in intermediate and capital goods causes a fall in the volatility of the trade balance. The other variables of the model show slightly larger variability in response to this type of change. This result can be explained with the following intuition: the representative household uses international markets less often to buy intermediate 
inputs and faces less fluctuations in the trade balance. The variability of other macro aggregates slightly increases, since she substitutes domestic capital into imported intermediate inputs more often, and this results in a rise in the volatility of investment. Changes in the relative weight of capital, s, have also similar effects on the moments of model variables.

The other two parameters, $v$ and $\sigma$, do not play an important role in the dynamics of the model. An increase in $v$ causes a minor decrease in the variability of labor hours. The volatility of the trade balance decreases in response to an increase in the risk aversion parameter, $\sigma$. When we simulate our model by changing the other parameters of our benchmark economy, we see that the results of the previous sections are quite robust to modest changes in those parameters. As one would expect, changes in the elasticity of marginal adjustment cost affects the volatility properties of model variables. In particular, higher elasticity values result in lower volatility of investment in the model. ${ }^{25}$

\section{Conclusion}

We examine the effects of trade shocks, namely fluctuations in the relative prices of capital goods to primary goods, and relative prices of intermediate goods to primary goods on macroeconomic fluctuations in African countries using a dynamic, stochastic, multi-sector, small, open economy model. The model is able to replicate volatility and comovement properties of sectoral outputs in African countries. Our estimations suggest that the trade shocks have a significant role in driving macroeconomic fluctuations in African economies. In particular, more than 44 percent of the variations in aggregate output is explained by trade shocks. Surprisingly, the world interest rate fluctuations have a minor effect on economic dynamics. Through impulse responses, we find that trade shocks cause prolonged recessions in these economies. Our sensitivity analysis suggests that the most significant impact of trade shocks is on the dynamics of investment in the model economy.

There are several interesting research issues we have not examined in this paper. As our model is the first dynamic model capturing main structural characteristics of these economies, we have not dealt with those issues associated with complex trade policies, well documented market rigidities, and political economy considerations all of which are very important aspects of African countries (see Collier and Gunning (1998).) Extensions of this model along these dimensions are important steps to be taken. In a recent paper, Rodrik (1998b) discusses the role of social conflict, and its interaction with external shocks, as an important source of poor economic performance of several developing countries. Extending this framework with political economy considerations is an interesting research avenue to be explored. Welfare costs of highly volatile trade shocks, and their interaction with high tariff rates should also be examined. We plan to examine welfare issues associated with trade shocks in a dynamic model with explicit treatment of different types of trade policies.

Understanding the role of trade shocks in driving economic activity is especially important in the design and conduct of macroeconomic policies. These issues have received widespread attention in policy circles, since most of the African economies have recently faced increasingly volatile prices in their export and import markets. In particular, analysis of the implications of government policies aiming to stabilize

\footnotetext{
${ }^{25}$ An extensive sensitivity analysis is available from the authors upon request.
} 
macroeconomic fluctuations induced by trade shocks, which have not been explored in a dynamic stochastic setting yet, seems to be a very exciting research avenue. 


\section{References}

Agenor, P. R., C. J. McDermott, and E. Prasad, 1998, Macroeconomic fluctuations in developing countries: some stylized facts, IMF Working Paper.

Ahearne, A. G., 1997, Trade liberalization and capital accumulation in developing economies, Working Paper, Carnegie Mellon University.

Aizenman, J., and N. Marion, 1993, Policy uncertainty, persistence and growth, Review of International Economics 1, 145-163.

Backus, D., Kehoe., P. and F. Kydland, 1995, International business cycles: Theory and evidence, in: Frontiers of Business Cycle Research, Thomas Cooley (ed.), Princeton University Press.

Balassa, B., 1978, Exports and economic growth: further evidence, Journal of Development Economics 5, 181-189.

Basu, P. and D. McLeod, 1992, Terms of trade fluctuations and economic growth in developing countries, Journal of Development Economics 37, 89-110.

Baxter, M., 1996, Are consumer durables important for business cycles?, Review of Economics and Statistics, 147-155.

Baxter, M., 1995, International trade and business cycles, in: Handbook of international economics, Gene Grossman and Kenneth Rogoff (eds), Amsterdam: North Holland.

Baxter, M., and M. Crucini, 1993, Explaining saving-investment correlations, American Economic Review 83, 416-436.

Berndt, E. R., and D. O. Wood, 1975, Technology, prices, and the derived demand for energy, Review of Economics and Statistics 57, 259-268.

Bevan, D., P. Collier, and J.W. Gunning, 1993, Trade shocks in developing economies, European Economic Review 37, 557-565.

Bevan, D., P. Collier, and J.W. Gunning, 1994, Controlled open economies, Clarendon Press-Oxford.

Borensztein, E., and C.M. Reinhart, 1994, The macroeconomic determinants of commodity prices, International Monetary Fund Staff Papers 41, 236-261.

Collier, P., and J.W. Gunning, 1998, Explaining African economic performance, Center for the Study of African Economies, Working Paper No: 97-2, forthcoming in the Journal of Economic Literature.

Collier, P., and J.W. Gunning, 1994, Trade shocks: consequences and policy responses in developing countries, International Center for Economic Growth.

Correia, I. , Neves, J.C. and S.Rebelo, 1995, Business cycles in a small open economy, European Economic Review 39, 1089-1113.

Deaton, A., and G. Laroque, 1992, On the behavior of commodity prices, Review of Economic Studies 59, 123.

Deaton, A., and R. Miller, 1996, International commodity prices, macroeconomic performance and politics in Sub-Saharan Africa, Journal of African Economies 5 (Supp.), 99-191. 
Easterly, W., M. Kremer, L. Pritchett, and L. H. Summers, 1993, Good policy or good luck? Country performance and temporary shocks, Journal of Monetary Economics 32, 459-483.

Easterly, W., and R. Levine, 1997, Africa's growth tragedy: policies and ethnic divisions, Quarterly Journal of Economics 112, 1203-1250.

Feder, G., 1983, On exports and economic growth, Journal of Development Economics 12, 195-218.

Fosu, A. K., 1996, The impact of external debt on economic growth in Sub-Saharan Africa, Journal of Economic Development 21, 93-118.

Gavin, M., and R. Hausman, 1996, Sources of macroeconomic volatility in developing economies, mimeo, Inter-American Development Bank.

Geder, G., 1983, On exports and economic growth, Journal of Development Economics 12, 59-73.

Ghosh, A. R., and J. D. Ostry, 1994, Export instability and the external balance in developing countries, International Monetary Fund Staff Papers 41, 214-235.

Ghura, D., and M. T. Hadjimichael, 1996, Growth in Sub-Saharan Africa, International Monetary Fund Staff Papers 43, 605-634.

Green, J., 1989, The external debt problem of Sub-Saharan Africa, International Monetary Fund Staff Papers $36,836-874$.

Greenwood, J., Hercowitz, Z. and G. Huffman, 1988, Investment, capacity utilization and the real business cycle, American Economic Review 78, 402-416.

Hadjimichael, M. T., D. Ghura, M. Muhleisen, R. Nord, and E M. Ucer, 1994, Effects of macroeconomic stability on growth, savings, and investment in Sub-Saharan Africa: An empirical investigation, IMF Working Paper No: 94/98.

Hentschel, J., 1992, Imports and Growth in Highly Indebted Countries, Springer-Verlag

Hodrick, R. J., and E. Prescott, 1997, Postwar U.S. business cycles: an empirical investigation, Journal of Money Credit and Banking 19, 1-16.

Hoffmaister, A. W., J. E. Roldos, and P. Wickham, 1998, Macroeconomic fluctuations in Sub-Saharan Africa, International Monetary Fund Staff Papers 45, 132-161.

Ingram, B., 1995, Recent advances in solving and estimating dynamic, stochastic macroeconomic models, in ed. K. Hoover, Macroeconometric Developments, Tensions and Prospects, Kluwer Academic Publishers, 1547.

King, R. G., C. Plosser, and S. Rebelo, 1988, Production, growth and business cycles: I. The basic neoclassical model, Journal of Monetary Economics 21, 195-232.

Kose, M. A., 1997a, Explaining business cycles in small open economies, working paper, Brandeis University.

Kose, M. A., 1997b, How important is international risksharing for developing economies?, working paper, Brandeis University. 
Kouparitsas, M., 1997a, North-South business cycles, mimeo, Federal Reserve Bank of Chicago.

Kouparitsas, M., 1997b, North-South terms-of-trade: An empirical investigation, working paper, Federal Reserve Bank of Chicago.

Kydland, F. and E. Prescott, 1996, The computational experiment: An econometric tool, Journal of Economic Literature 10, 69-87.

Maizels, A., 1995, The functioning of international markets for primary commodities: key policy issues for developing countries, International Monetary and Financial Issues for the 1990s, v.5, United Nations.

Mendoza, E.G., 1995, The terms of trade, the real exchange rate, and economic fluctuations, International Economic Review 36, 101-137.

Michaely, M., 1984, Trade, income levels and dependence, North-Holland.

Moran, C., 1983, Export fluctuations and economic growth, Journal of Development Economics 12, 195218.

Ostry, J. D. and C. Reinhart, 1992, Private saving and terms of trade shocks, International Monetary Fund Staff Papers 39, 495-517

Ozler, S., and D. Rodrik, 1992, External shocks, politics, and private investment, Journal of Development Economics 39, 141-162.

Pindyck, R. S., 1991, Irreversibility, uncertainty, and investment, Journal of Economic Literature 29, 11101148.

Ramey, G., and V. A. Ramey, 1995, Cross-country evidence on the link between volatility and growth, American Economic Review 85, 1138-1151.

Rebelo, S. and C. A. Vegh, 1995, Real effects of exchange-rate-based stabilization: an analysis of competing theories, Rochester Center for Economic Research, Working Paper No. 405.

Reinhart, C. M., and P. Wickham, 1994, Commodity prices: Cyclical weakness or secular decline, International Monetary Fund Staff Papers 41, 175-213.

Rodrik, D., 1998a, Trade policy and economic performance in Sub-Saharan Africa, NBER working paper series, No: 6562.

Rodrik, D., 1998b, Where did all the growth go? External shocks, social conflict, and growth collapses, NBER working paper series, No: 6350.

Sachs, J. D., 1989, Developing country debt and the world economy, University of Chicago Press.

Sachs, J. D., and M. Warner, 1996, Sources of slow growth in African economies, Journal of African Economies 5 (Supp.), 335-376.

Sato, K., 1967, A two-level constant-elasticity-of-substitution production function, Review of Economic Studies 34, 201-218.

Senhadji, A., 1995, Sources of debt accumulation in a small open economy, mimeo, Washington University at St. Louis. 
United Nations, United Nations conference on trade and development (UNCTAD) Handbook of international trade and development statistics, several issues, United Nations, New York.

Van Wincoop, E., 1992, Terms-of-trade uncertainty, savings, and the production structure, Journal of International Economics 33, 305-325.

Varangis, P., T. Akiyama and D. Mitchell, 1995, Managing Commodity Booms-and Busts, Directions in Development, World Bank, Washington, D.C.

World Bank, 1994, World Tables, World Bank, Washington, D.C..

World Bank, 1995, Commodity Markets and the Developing Countries 2, World Bank, Washington, D.C. 


\begin{tabular}{|c|c|c|c|c|c|c|c|c|c|c|c|c|}
\hline \multicolumn{13}{|c|}{$\begin{array}{c}\text { Table 1a } \\
\text { Decomposition of GDP } \\
\text { (in percent) }\end{array}$} \\
\hline \multicolumn{8}{|c|}{ Expenditure Shares } & \multicolumn{5}{|c|}{ Industrial Structure } \\
\hline Country & Gvt. & Con. & Inv. & Exp. & Imp. & T.V. & T.B. & Agr. & Ind. & Man. & Con. & Ser. \\
\hline$\underline{\text { African }}$ & & & & & & & & & & & & \\
\hline Mean & 17.0 & 69.6 & 22.9 & 30.8 & 40.4 & 71.1 & -9.6 & 28.0 & 18.2 & 11.2 & 5.3 & 48.5 \\
\hline $\begin{array}{c}\text { Med. } \\
\text { G7 }\end{array}$ & 16.3 & 68.8 & 23.3 & 26.8 & 34.8 & 60.8 & -7.2 & 28.8 & 16.2 & 10.2 & 4.8 & 48.2 \\
\hline$\overline{\text { Mean }}$ & 16.6 & 59.3 & 23.9 & 19.7 & 18.3 & 38.0 & 1.3 & 3.7 & 29.7 & 25.4 & 6.6 & 60.0 \\
\hline Med. & 18.0 & 59.0 & 24.3 & 20.3 & 20.3 & 40.7 & 0.7 & 3.7 & 28.0 & 23.8 & 6.3 & 62.0 \\
\hline $\begin{array}{l}\text { Gvt. }=\text { gov } \\
\text { imports; } \mathrm{Tr} \\
\text { quarrying }+ \\
\text { data of } 22 \\
1970,1980\end{array}$ & $\begin{array}{l}\text { rnment } \\
\text { de Vol.= } \\
\text { electrici } \\
\text { on-oil ex } \\
\text { and 199 }\end{array}$ & $\begin{array}{l}\text { lal expe } \\
\text { xp.+Im } \\
+ \text { gas+w } \\
\text { rting A } \\
\text { The sou }\end{array}$ & $\begin{array}{l}\text { ture; C } \\
\text { GDP; T } \\
\text {; Man. } \\
\text { in econ } \\
\text { of the d }\end{array}$ & $\begin{array}{l}\mathrm{s} \text { and } \\
\text { the } \mathrm{H} \text {. }\end{array}$ & $\begin{array}{l}\text {; Cons } \\
\text { countrie } \\
\text { oook of }\end{array}$ & tion $\mathrm{e}$ & $\begin{array}{l}\text { Ser.= } \\
\text { the cou } \\
\text { rade an }\end{array}$ & ices. & $\begin{array}{l}\text { the } n \\
\text { mple, } \\
\text { Statis }\end{array}$ & $\begin{array}{l}\text { and } m \\
\text { ata are } \\
\text { variou }\end{array}$ & $\begin{array}{l}x p=e x \\
\text { cturin } \\
\text { A value } \\
\text { rages }\end{array}$ & $\begin{array}{l}\text { s; Imp. } \\
\text { ining an } \\
\text { e use th } \\
\text { the year }\end{array}$ \\
\hline
\end{tabular}

\begin{tabular}{|c|c|c|c|c|c|c|c|c|c|c|c|}
\hline \multicolumn{12}{|c|}{$\begin{array}{c}\text { Table } 1 \mathrm{~b} \\
\text { Decomposition of Exports } \\
\text { (in percent) }\end{array}$} \\
\hline Country & Food & Agr. & Metals & Prima. & Man. & Cap. & Inter. & Fuels & $\begin{array}{l}\text { Total } \\
\text { Inter. }\end{array}$ & $\begin{array}{l}\text { Num. } \\
\text { Exp. }\end{array}$ & $\begin{array}{c}\text { Concen } \\
\text { Index } \\
\end{array}$ \\
\hline \multicolumn{12}{|l|}{ African } \\
\hline$\overline{\text { Mean }}$ & 47.4 & 9.7 & 20.0 & 77.1 & 14.4 & 1.8 & 12.7 & 6.9 & 19.7 & 54.3 & 60.1 \\
\hline $\begin{array}{l}\text { Median } \\
\text { G7 }\end{array}$ & 52.4 & 4.6 & 6.9 & 82.6 & 9.8 & 0.9 & 7.8 & 1.3 & 11.4 & 44.0 & 64.4 \\
\hline Mean & 8.9 & 3.2 & 4.6 & 16.7 & 76.8 & 40.7 & 36.2 & 4.5 & 40.7 & 213 & 9.6 \\
\hline Median & 7.3 & 1.6 & 3.6 & 12.8 & 76.9 & 38.5 & 39.4 & 3.5 & 42.9 & 216 & 9.1 \\
\hline \multicolumn{12}{|c|}{$\begin{array}{l}\text { *Agr. = agricultural raw materials; Primary }=\text { Food+Agr.+Metals; Man.=manufactured goods; Cap.=capital goods=machinery and equipment; } \\
\text { Inter. = intermediate inputs(all manufactured items less machinery); Total Inter.= Inter+Fuels; Number Exp.=number of commodities exported; } \\
\text { Concen. Index= export concentration index. To get the mean and median values, we use the data of } 22 \text { non-oil exporting African economies and } \\
\text { G7 countries. For most of the countries in our sample, the data are averages over the years } 1970,1980 \text {, and 1990. The source of the data is the } \\
\text { Handbook of International Trade and Development Statistics (various years). }\end{array}$} \\
\hline
\end{tabular}

\begin{tabular}{|c|c|c|c|c|c|c|c|c|c|}
\hline \multicolumn{10}{|c|}{$\begin{array}{c}\text { Table 1c } \\
\text { Decomposition of Imports } \\
\text { (in percent) }\end{array}$} \\
\hline Country & Food & Agr. & Metals & Primary & Man. & Cap. & Inter. & Fuels & $\begin{array}{l}\text { Total } \\
\text { Inter. }\end{array}$ \\
\hline \multicolumn{10}{|l|}{ African } \\
\hline Mean & 19.3 & 2.5 & 1.6 & 23.4 & 63.3 & 27.8 & 35.5 & 12.0 & 47.5 \\
\hline \multicolumn{10}{|l|}{ G7 } \\
\hline$\overline{\text { Mean }}$ & 12.6 & 5.3 & 7.1 & 25.0 & 57.1 & 26.9 & 30.3 & 16.4 & 46.6 \\
\hline Median & 13.6 & 4.6 & 7.2 & 25.5 & 60.0 & 24.1 & 30.2 & 16.1 & 48.1 \\
\hline $\begin{array}{l}{ }^{*} \text { Agr. }=\text { agri } \\
\text { Inter.= inter } \\
\text { Concen. Ind } \\
\text { G7 countrie } \\
\text { Handbook o }\end{array}$ & $\begin{array}{l}\text { al raw } \\
\text { ate inpu } \\
\text { xport cc } \\
\text { most o } \\
\text { rnation }\end{array}$ & $\begin{array}{l}\text { als; Prin } \\
\text { nanufac } \\
\text { ration in } \\
\text { countries } \\
\text { le and D }\end{array}$ & $\begin{array}{l}\text { Food }+\mathrm{Ag} \\
\text { items less } \\
\text { To get the } \\
\text { ur sample, } \\
\text { pment Stat }\end{array}$ & $\begin{array}{l}\text { Metals; Mar } \\
\text { chinery); To } \\
\text { an and medi } \\
\text { data are ave } \\
\text { cs (various y }\end{array}$ & $\begin{array}{l}\text { nanufact } \\
\text { Inter.= I } \\
\text { alues, w } \\
\text { es over } \\
\text { ). }\end{array}$ & $\begin{array}{l}\text { oods; C } \\
\text { uels; } \mathrm{Nu} \\
\text { he data } \\
\text { irs } 1970 \text {, }\end{array}$ & $\begin{array}{l}\text { apital go } \\
\text { Exp.=nu } \\
\text { non-oil e } \\
\text { and } 199\end{array}$ & $\begin{array}{l}\text { lachinery } \\
\text { of comm } \\
\text { ng Africe } \\
\text { e source }\end{array}$ & $\begin{array}{l}\text { equipme } \\
\text { es export } \\
\text { nnomies a } \\
\text { data is }\end{array}$ \\
\hline
\end{tabular}




\begin{tabular}{|c|c|c|c|c|c|c|c|}
\hline \multicolumn{8}{|c|}{$\begin{array}{c}\text { Table } 2 \\
\text { Debt Indicators } \\
\text { (in percent) }\end{array}$} \\
\hline & ED/GNP & IN/GNP & ED/EXP & TD/EXP & IN/EXP & SH/EXP & SH/ED \\
\hline Mean & 89.0 & 3.0 & 379.3 & 19.9 & 9.5 & 42.6 & 12.3 \\
\hline Median & 76.8 & 2.6 & 263.0 & 19.7 & 8.6 & 27.5 & 9.3 \\
\hline
\end{tabular}

\section{Table 3}

\section{Properties of Macroeconomic Fluctuations*}

Volatility

\begin{tabular}{lcccccccccccc}
\hline & $\boldsymbol{\sigma}_{\mathbf{y}}$ & $\boldsymbol{\sigma}_{\text {ind+ser }}$ & $\boldsymbol{\sigma}_{\text {agr }}$ & $\boldsymbol{\sigma}_{\text {ind }}$ & $\boldsymbol{\sigma}_{\text {man }}$ & $\boldsymbol{\sigma}_{\text {ser }}$ & $\boldsymbol{\sigma}_{\mathbf{c}}$ & $\boldsymbol{\sigma}_{\mathbf{i}}$ & $\boldsymbol{\sigma}_{\text {emp }}$ & $\boldsymbol{\sigma}_{\text {tb }}$ & $\boldsymbol{\sigma}_{\text {exp }}$ & $\boldsymbol{\sigma}_{\text {imp }}$ \\
\hline Mean & 4.10 & 4.83 & 7.99 & 9.51 & 10.68 & 5.38 & 8.28 & 15.69 & 7.33 & 16.45 & 12.73 & 13.51 \\
Median & 3.93 & 4.86 & 8.36 & 7.41 & 7.24 & 5.01 & 8.65 & 15.26 & 6.26 & 15.25 & 12.77 & 13.89 \\
\hline
\end{tabular}

\section{Persistence}

\begin{tabular}{lccccccccccc}
\hline & $\rho_{\mathbf{y}}$ & $\rho_{\text {agr }}$ & $\rho_{\text {ind }}$ & $\rho_{\text {man }}$ & $\rho_{\text {ser }}$ & $\rho_{\text {c }}$ & $\rho_{\text {i }}$ & $\rho_{\text {emp }}$ & $\rho_{\text {tb }}$ & $\rho_{\text {exp }}$ & $\rho_{\text {imp }}$ \\
\hline Mean & 0.34 & 0.15 & 0.39 & 0.41 & 0.33 & 0.32 & 0.35 & 0.42 & 0.36 & 0.27 & 0.43 \\
Median & 0.40 & 0.16 & 0.46 & 0.44 & 0.33 & 0.37 & 0.41 & 0.47 & 0.42 & 0.28 & 0.47 \\
\hline
\end{tabular}

\section{Comovement}

\begin{tabular}{lcccccccccc}
\hline & $\rho_{\text {agr }, \mathbf{y}}$ & $\rho_{\text {ind,y }}$ & $\rho_{\text {man }, \mathbf{y}}$ & $\rho_{\text {ser }, \mathbf{y}}$ & $\rho_{\mathbf{c}, \mathbf{y}}$ & $\rho_{\mathbf{i}, \mathbf{y}}$ & $\rho_{\text {emp,y }}$ & $\rho_{\text {tb,y }}$ & $\rho_{\text {exp,y }}$ & $\rho_{\text {imp }, \mathbf{y}}$ \\
\hline Mean & 0.51 & 0.62 & 0.59 & 0.71 & 0.39 & 0.46 & 0.22 & -0.10 & 0.29 & 0.28 \\
Median & 0.61 & 0.74 & 0.75 & 0.77 & 0.55 & 0.50 & 0.23 & -0.19 & 0.32 & 0.23 \\
\hline
\end{tabular}

$\sigma_{\mathrm{x}}$ is the percent standard deviation of the variable $\mathrm{x} . \rho_{\mathrm{x}}$ is the first-order serial autocorrelation of the variable $\mathrm{x}$. $\rho_{\mathrm{x}, \mathrm{y}}$ is the contemporaneous correlation between the variables $\mathrm{x}$ and $\mathrm{y}$. $\mathrm{y}=$ aggregate output=ind+ser+agr= industrial activity (manufacturing+mining and quarrying+electricity+gas+water)+services+agriculture; agr=agriculture; ind=industrial activity (manufacturing+mining and quarrying + electricity +gas+water); $m a n=$ manufacturing; $s e r=$ services; $c=$ private final consumption expenditure; $i=$ gross domestic investment; emp= labor supply; $\mathrm{t}=(\mathrm{exp}-\mathrm{imp}) / \mathrm{y}$; exp=exports; imp= imports. The data is in terms of real domestic prices, constructed for per capita quantities, logged and filtered using HP(100) filter. To get the mean and median values, we use the data of 22 non-oil exporting African economies. The data, for the period 1970-1992, comes from the World Bank World Tables (1994.) See Appendix A2 for more information about the data.

\section{Table 4}

\section{Properties of Price Fluctuations*}

\begin{tabular}{lccccccc} 
& \multicolumn{3}{c}{ Volatility } & & \multicolumn{3}{c}{ Persistence } \\
\cline { 2 - 4 } \cline { 6 - 8 } & $\sigma_{\mathbf{p k}}$ & $\sigma_{\mathbf{p v}}$ & $\sigma_{\mathbf{t o t}}$ & & $\rho_{\mathbf{p k}}$ & $\rho_{\mathbf{p v}}$ & $\rho_{\text {tot }}$ \\
\hline Mean & 14.36 & 12.97 & 11.67 & 0.38 & 0.35 & 0.22 \\
Median & 13.62 & 11.81 & 11.36 & & 0.40 & 0.36 & 0.26 \\
\hline
\end{tabular}

\begin{tabular}{|c|c|c|c|c|c|c|c|c|}
\hline & \multicolumn{8}{|c|}{ Comovement } \\
\hline & $\rho_{\mathrm{pk}, \mathrm{tb}}$ & $\rho_{\mathrm{pv}, \mathrm{tb}}$ & $\rho_{\text {tot }, \text { tb }}$ & $\rho_{\mathrm{pk}, \mathrm{y}}$ & $\rho_{\mathrm{pv}, y}$ & $\rho_{\text {tot, } y}$ & $\rho_{\mathrm{pk}, \mathrm{tot}}$ & $\rho_{\mathrm{pv}, \text { tot }}$ \\
\hline Mean & -0.26 & -0.23 & 0.34 & -0.08 & -0.05 & 0.03 & $\frac{1}{-0.67}$ & -0.71 \\
\hline Median & -0.24 & -0.28 & 0.41 & -0.06 & -0.02 & -0.02 & -0.70 & -0.77 \\
\hline
\end{tabular}

\footnotetext{
${ }^{*} \sigma_{\mathrm{x}}$ is the percent standard deviation of the variable $\mathrm{x} . \rho_{\mathrm{x}}$ is the first-order serial autocorrelation of the variable x. $\rho_{\mathrm{x}, \mathrm{y}}$ is the contemporaneous correlation between the variables $\mathrm{x}$ and $\mathrm{y}$. $\mathrm{pk}=$ the relative price of the capital goods to export price index; $\mathrm{pv}=$ the relative price of the intermediate inputs to the export price index; tot=terms-of-trade; $t b=$ trade balance; $y=$ aggregate output. The data is in terms of real domestic prices, constructed for per capita quantities, logged and filtered using HP(100) filter. To get the mean and median values, we use the data of 22 non-oil exporting African economies. See Appendix A2 for more information about the data.
} 


\begin{tabular}{lll}
\hline Parameter Description & Value \\
\hline
\end{tabular}

\section{Preferences}

$\begin{array}{cll}\beta & \text { Discount factor } & 0.97 \\ \mathrm{r} & \text { Real interest rate, } r=(1 / \beta)-1 & 0.035 \\ 1 /(v-1) & \text { Intertemporal elasticity of substitution in labor supply } & 0.83 \\ \sigma & \text { Coefficient of relative risk aversion } & 2.61 \\ \psi & \text { Level parameter for labor supply } & 5.35\end{array}$

\section{$\underline{\text { Technology }}$}

Primary Goods Sector

$\begin{array}{lll}\theta_{1} & \text { Share of labor income } & 0.37\end{array}$

$\begin{array}{lll}\theta_{2} & \text { Share of capital income } & 0.18\end{array}$

$\eta_{p} \quad$ Elasticity of marginal adjustment cost function $\quad 2.2$

$$
\eta_{p}=-\left(\phi^{\prime} / \phi^{\prime \prime}\right) /\left(i_{p} / k_{p}\right)
$$

Final Goods Sector

\begin{tabular}{cll}
$\alpha$ & Share of labor income & 0.45 \\
$\mathrm{~s}_{\mathrm{k}}$ & Share of capital income & 0.23 \\
$\mathrm{~s}_{\mathrm{v}}$ & Share of intermediate input income & 0.32 \\
$1 /(u+1)$ & Elasticity of substitution between intermediate and capital & 0.77 \\
& goods & \\
$\sigma_{k, v}$ & Allen elasticity of substitution between intermediate and capital & 0.55 \\
$\delta$ & goods & 0.10 \\
$t b /\left(y^{p}+y^{f}\right)$ & Depreciation rate & -0.096 \\
$\eta_{f}$ & Trade balance to aggregate output ratio & 2 \\
\hline & Elasticity of marginal adjustment cost function & \\
\hline See section 4 for details about the calibration of the model. & \\
\hline
\end{tabular}




\begin{tabular}{|c|c|c|}
\hline \multicolumn{3}{|c|}{$\begin{array}{c}\text { Table } 6 \\
\text { Properties of Macroeconomic Fluctuations } \\
\text { (African Average) }\end{array}$} \\
\hline Variable & Volatility & Comovement \\
\hline Output & $\begin{array}{c}4.10 \\
(1.41)\end{array}$ & 1.00 \\
\hline Primary & $\begin{array}{c}7.99 \\
(3.57)\end{array}$ & $\begin{array}{c}0.51 \\
(0.36)\end{array}$ \\
\hline Final & $\begin{array}{c}4.83 \\
(1.53)\end{array}$ & $\begin{array}{c}0.62 \\
(0.33)\end{array}$ \\
\hline Consumption & $\begin{array}{c}8.28 \\
(3.80)\end{array}$ & $\begin{array}{c}0.39 \\
(0.43)\end{array}$ \\
\hline Investment & $\begin{array}{l}15.69 \\
(4.52)\end{array}$ & $\begin{array}{c}0.46 \\
(0.26)\end{array}$ \\
\hline Employment & $\begin{array}{c}7.33 \\
(4.48)\end{array}$ & $\begin{array}{c}0.22 \\
(0.45)\end{array}$ \\
\hline Trade Balance & $\begin{array}{l}16.45 \\
(6.15) \\
\end{array}$ & $\begin{array}{l}-0.10 \\
(0.30)\end{array}$ \\
\hline
\end{tabular}

All moments are averages over the moments of 22 non-oil exporting African countries whose business cycle statistics are given in tables (A1)-(A5). The data is in terms of real domestic prices, constructed for per capita quantities, logged and filtered using $\mathrm{HP}(100)$ filter. Volatility is the percentage deviation from the HP trend. Comovement is the contemporenous correlation with the output. The sample standard errors of the averages are given in parenthesis. The data, for the period 1970-1992, comes from the World Bank World Tables (1994). See Appendix A2 for more information about the data.

\begin{tabular}{|c|c|c|}
\hline \multicolumn{3}{|c|}{$\begin{array}{c}\text { Table } 7 \\
\text { Properties of Macroeconomic Fluctuations* } \\
\text { (Model) }\end{array}$} \\
\hline Variable & Volatility & Comovement \\
\hline Output & $\begin{array}{c}4.93 \\
(0.03)\end{array}$ & 1.00 \\
\hline Primary & $\begin{array}{c}6.20 \\
(0.03)\end{array}$ & $\begin{array}{c}0.57 \\
(0.01)\end{array}$ \\
\hline Final & $\begin{array}{c}5.32 \\
(0.03)\end{array}$ & $\begin{array}{c}0.98 \\
(0.00)\end{array}$ \\
\hline Consumption & $\begin{array}{c}4.98 \\
(0.03)\end{array}$ & $\begin{array}{c}0.77 \\
(0.00)\end{array}$ \\
\hline Investment & $\begin{array}{l}15.69 \\
(0.09)\end{array}$ & $\begin{array}{c}0.69 \\
(0.00)\end{array}$ \\
\hline Labor Hours & $\begin{array}{c}3.40 \\
(0.02)\end{array}$ & $\begin{array}{c}0.77 \\
(0.00)\end{array}$ \\
\hline Trade Balance & $\begin{array}{r}19.81 \\
(0.11) \\
\end{array}$ & $\begin{array}{r}-0.72 \\
(0.01) \\
\end{array}$ \\
\hline \multicolumn{3}{|c|}{$\begin{array}{l}\text { All moments are averages over the } 1000 \text { simulations of the model each with } 23 \text { observations (the } \\
\text { sample data has also } 23 \text { observations (1970-1992)). The simulated data is filtered by HP(100). } \\
\text { Volatility is the percentage deviation from the HP trend. Comovement is the contemporenous } \\
\text { correlation with the output. The asymptotic standard deviations of the statistics are given in } \\
\text { parenthesis. }\end{array}$} \\
\hline
\end{tabular}




\begin{tabular}{|c|c|c|c|c|c|c|c|}
\hline \multicolumn{8}{|c|}{$\begin{array}{c}\text { Table 8 } \\
\begin{array}{c}\text { Variance Decomposition } \\
\text { (in percent) }\end{array} \\
\end{array}$} \\
\hline \multirow[b]{2}{*}{ Variable } & \multicolumn{3}{|c|}{ Trade Shocks } & \multirow{2}{*}{$\begin{array}{c}\text { World } \\
\text { Interest } \\
\text { Rate }\end{array}$} & \multicolumn{3}{|c|}{$\begin{array}{c}\text { Technology Shocks } \\
\end{array}$} \\
\hline & $\begin{array}{l}\text { Capital } \\
\text { Goods }\end{array}$ & $\begin{array}{c}\text { Intermediate } \\
\text { Inputs }\end{array}$ & Total & & $\begin{array}{l}\text { Final } \\
\text { Goods }\end{array}$ & $\begin{array}{c}\text { Primary } \\
\text { Goods }\end{array}$ & Total \\
\hline Output & 24.72 & 19.92 & 44.64 & 0.87 & 52.77 & 1.71 & 54.49 \\
\hline Primary & 37.94 & 15.77 & 53.71 & 2.15 & 9.44 & 34.70 & 44.15 \\
\hline Final & 24.05 & 21.59 & 45.64 & 1.69 & 51.41 & 1.27 & 52.67 \\
\hline Consumption & 43.6 & 35.54 & 79.14 & 2.89 & 15.77 & 2.20 & 17.97 \\
\hline Investment & 52.77 & 33.59 & 86.36 & 0.46 & 12.81 & 0.37 & 13.17 \\
\hline Primary & 98.7 & 0.7 & 99.40 & 0.15 & 0.32 & 0.12 & 0.44 \\
\hline Final & 42.34 & 40.78 & 83.12 & 0.8 & 15.45 & 0.64 & 16.09 \\
\hline Intermediate Goods & 49.78 & 42.42 & 92.20 & 1.83 & 4.48 & 1.48 & 5.96 \\
\hline Labor Hours & 42.8 & 37.97 & 80.77 & 1.41 & 16.56 & 1.26 & 17.82 \\
\hline Primary & 42.53 & 29.47 & 72.00 & 3.11 & 14.98 & 9.91 & 24.89 \\
\hline Final & 43.44 & 35.79 & 79.23 & 3.22 & 14.91 & 2.64 & $\mathbf{1 7 . 5 5}$ \\
\hline Trade Balance & 41.18 & 32.54 & 73.72 & 4.57 & 12.87 & 8.84 & 21.71 \\
\hline Asset Holdings & 45.77 & 30.50 & 76.27 & 5.84 & 13.36 & 4.52 & 17.88 \\
\hline
\end{tabular}




\begin{tabular}{|c|c|c|c|c|}
\hline \multicolumn{5}{|c|}{$\begin{array}{c}\text { Table } 9 \\
\text { Properties of Macroeconomic Fluctuations } * \\
\text { (Model) }\end{array}$} \\
\hline \multirow[b]{2}{*}{ Variable } & \multicolumn{2}{|c|}{ With Productivity Shocks } & \multicolumn{2}{|c|}{\begin{tabular}{|l} 
With Price Shocks \\
\end{tabular}} \\
\hline & Volatility & Comovement & Volatility & Comovement \\
\hline Output & $\begin{array}{c}4.46 \\
(0.03)\end{array}$ & 1.00 & $\begin{array}{c}1.18 \\
(0.01)\end{array}$ & 1.00 \\
\hline Primary & $\begin{array}{c}5.54 \\
(0.03)\end{array}$ & $\begin{array}{c}0.45 \\
(0.01)\end{array}$ & $\begin{array}{c}2.58 \\
(0.02)\end{array}$ & $\begin{array}{c}0.95 \\
(0.00)\end{array}$ \\
\hline Final & $\begin{array}{c}4.97 \\
(0.03)\end{array}$ & $\begin{array}{c}0.97 \\
(0.00)\end{array}$ & $\begin{array}{c}0.93 \\
(0.01)\end{array}$ & $\begin{array}{c}0.98 \\
(0.00)\end{array}$ \\
\hline Consumption & $\begin{array}{c}2.08 \\
(0.01)\end{array}$ & $\begin{array}{c}0.99 \\
(0.00)\end{array}$ & $\begin{array}{c}3.95 \\
(0.02)\end{array}$ & $\begin{array}{c}0.86 \\
(0.00)\end{array}$ \\
\hline Investment & $\begin{array}{c}5.46 \\
(0.03)\end{array}$ & $\begin{array}{c}0.97 \\
(0.00)\end{array}$ & $\begin{array}{l}13.23 \\
(0.07)\end{array}$ & $\begin{array}{c}0.78 \\
(0.00)\end{array}$ \\
\hline Labor Hours & $\begin{array}{c}1.42 \\
(0.01)\end{array}$ & $\begin{array}{c}0.99 \\
(0.00)\end{array}$ & $\begin{array}{c}2.70 \\
(0.01)\end{array}$ & $\begin{array}{c}0.84 \\
(0.00)\end{array}$ \\
\hline Trade Balance & $\begin{array}{r}12.54 \\
(0.07) \\
\end{array}$ & $\begin{array}{c}-0.66 \\
(0.00) \\
\end{array}$ & $\begin{array}{r}14.04 \\
(0.08) \\
\end{array}$ & $\begin{array}{l}-0.85 \\
(0.00) \\
\end{array}$ \\
\hline $\begin{array}{l}\text { All moments are } \\
\text { observations (1970- } \\
\text { Relative volatility i } \\
\text { the contemporenous }\end{array}$ & $\begin{array}{l}\text { er the } 1000 \mathrm{~s} \\
\text { imulated data } \\
\text { deviation of } \mathrm{t} \\
\text { ith the output. }\end{array}$ & $\begin{array}{l}\text { of the model ea } \\
\text { by HP(100) filter. } \\
\text { ive variable relative } \\
\text { pptotic standard dev }\end{array}$ & $\begin{array}{l}3 \text { observations } \\
\text { is the percenta } \\
\text { andard deviatio } \\
\text { the statistics ar }\end{array}$ & $\begin{array}{l}\text { ple data has also } \\
\text { on from the HP trer } \\
\text { utput. Comovement } \\
\text { parenthesis. }\end{array}$ \\
\hline
\end{tabular}


1a. Non-Fuel Commodity Prices

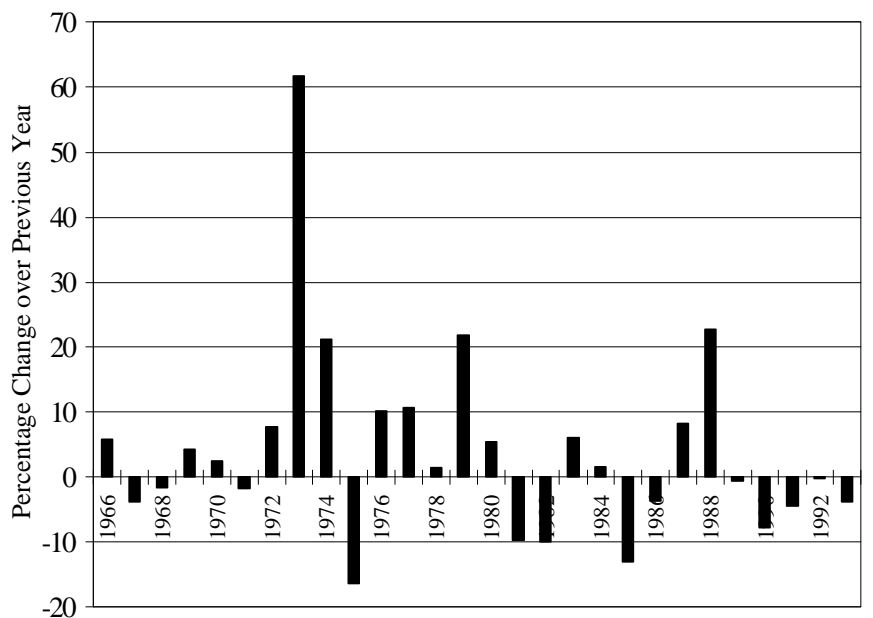

1c. Relative Prices of Capital Goods

(Africa)

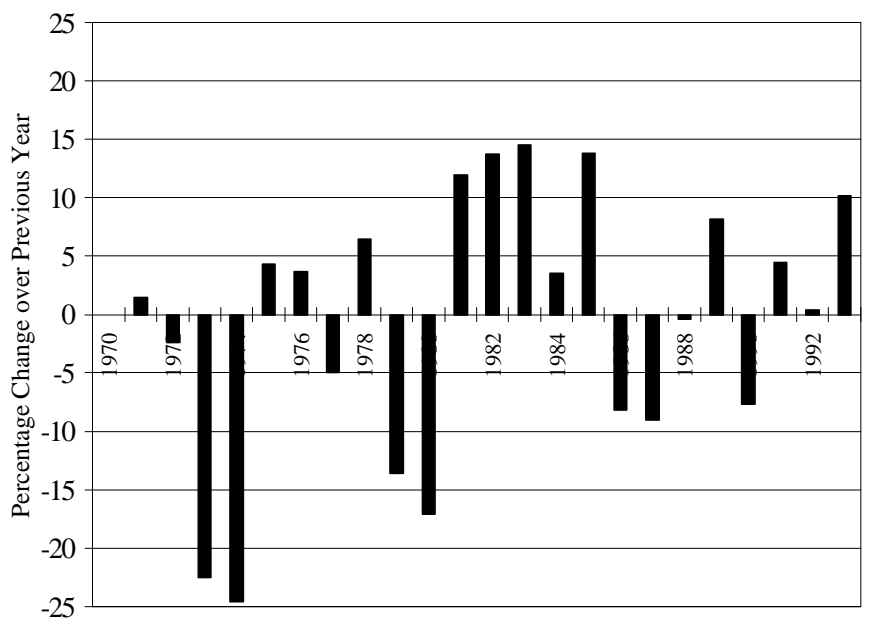

1e. Terms of Trade

(Africa)

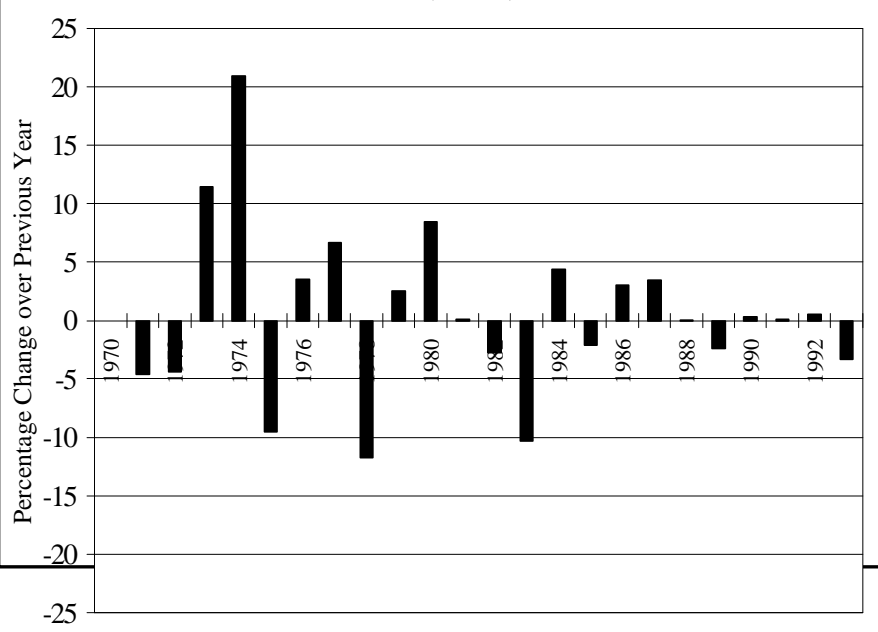

1b. Prices of Agricultural Commodities

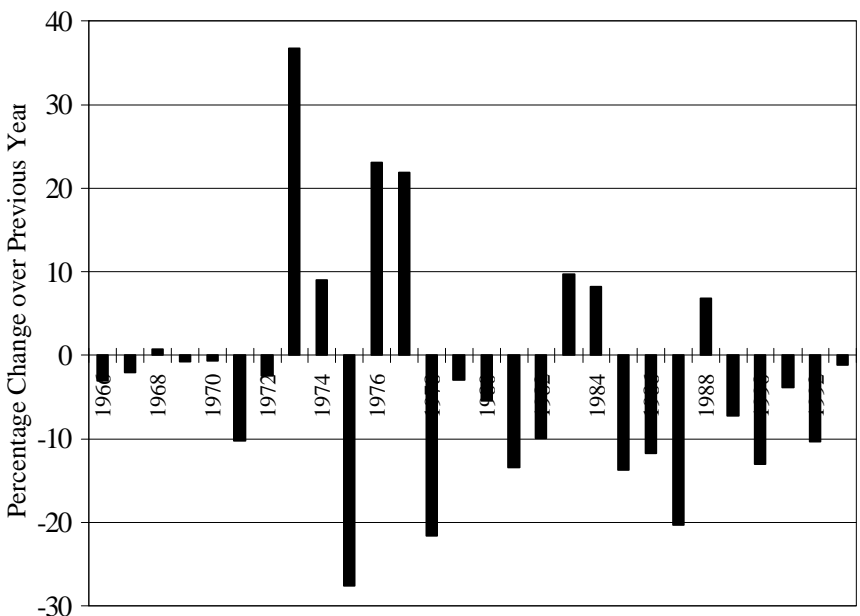

1d. Relative Prices of Intermediate Inputs

(Africa)

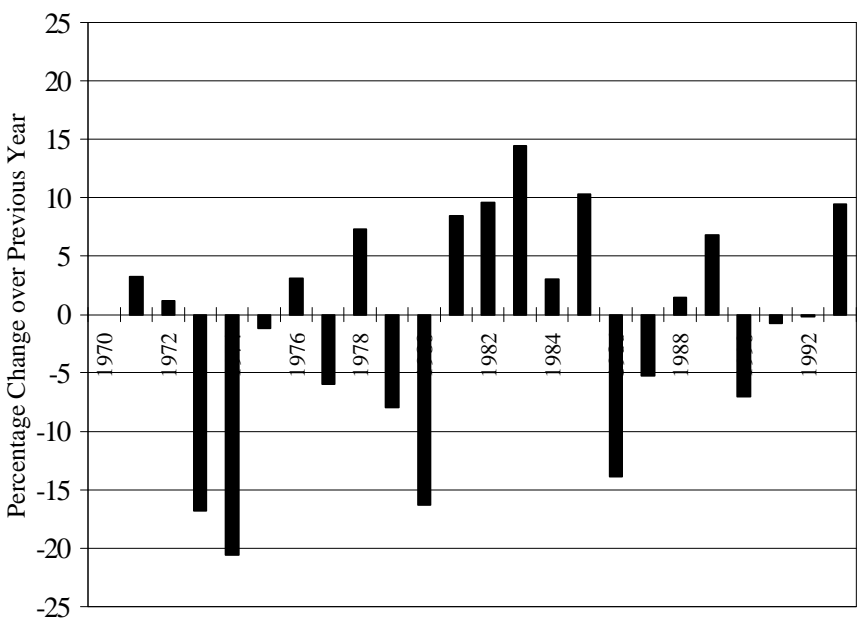

1f. World Real Interest Rate

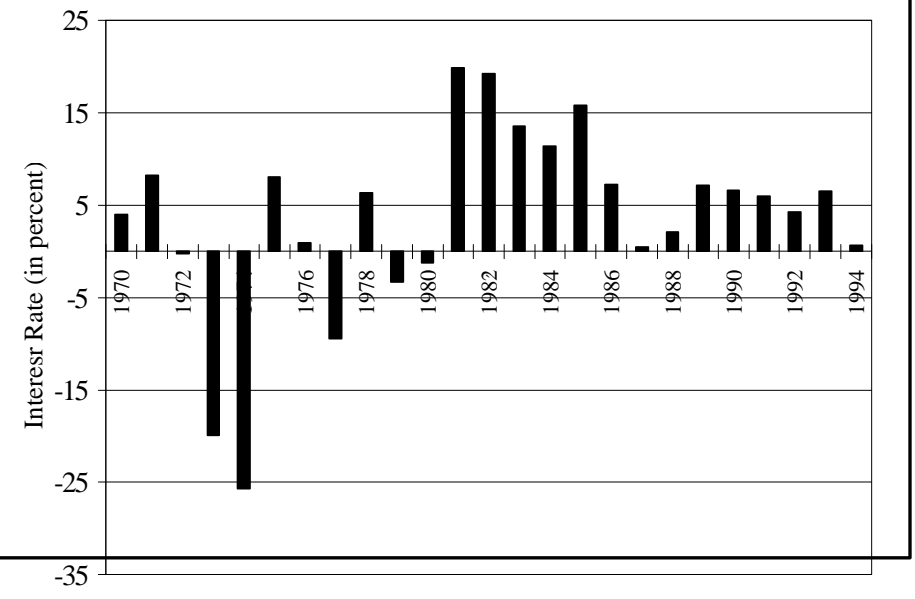




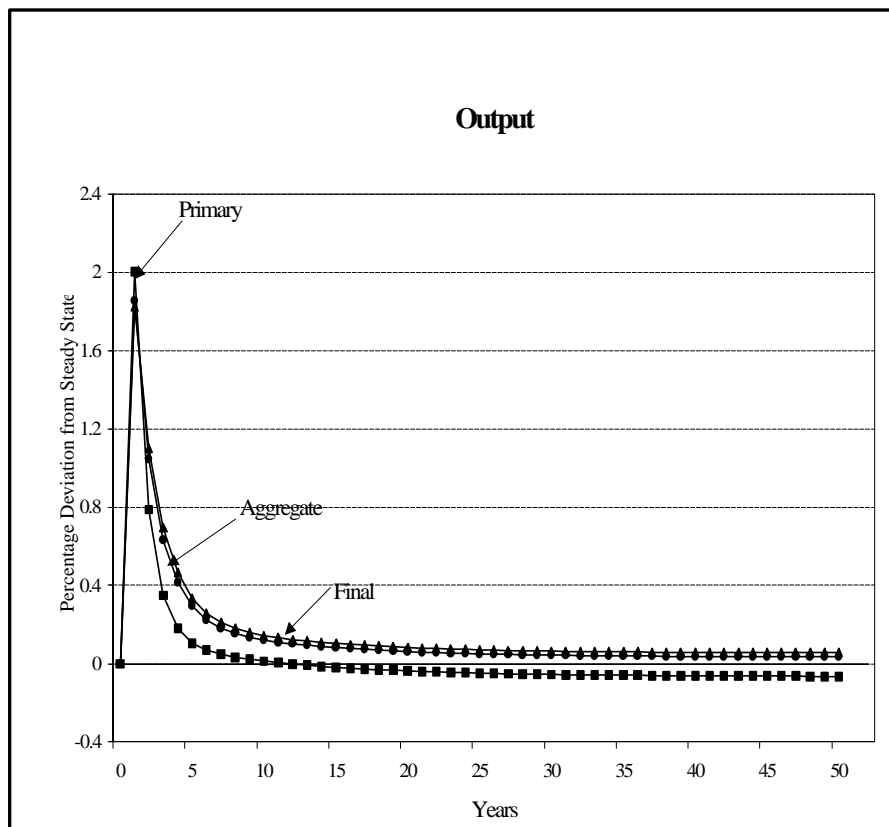

Investment
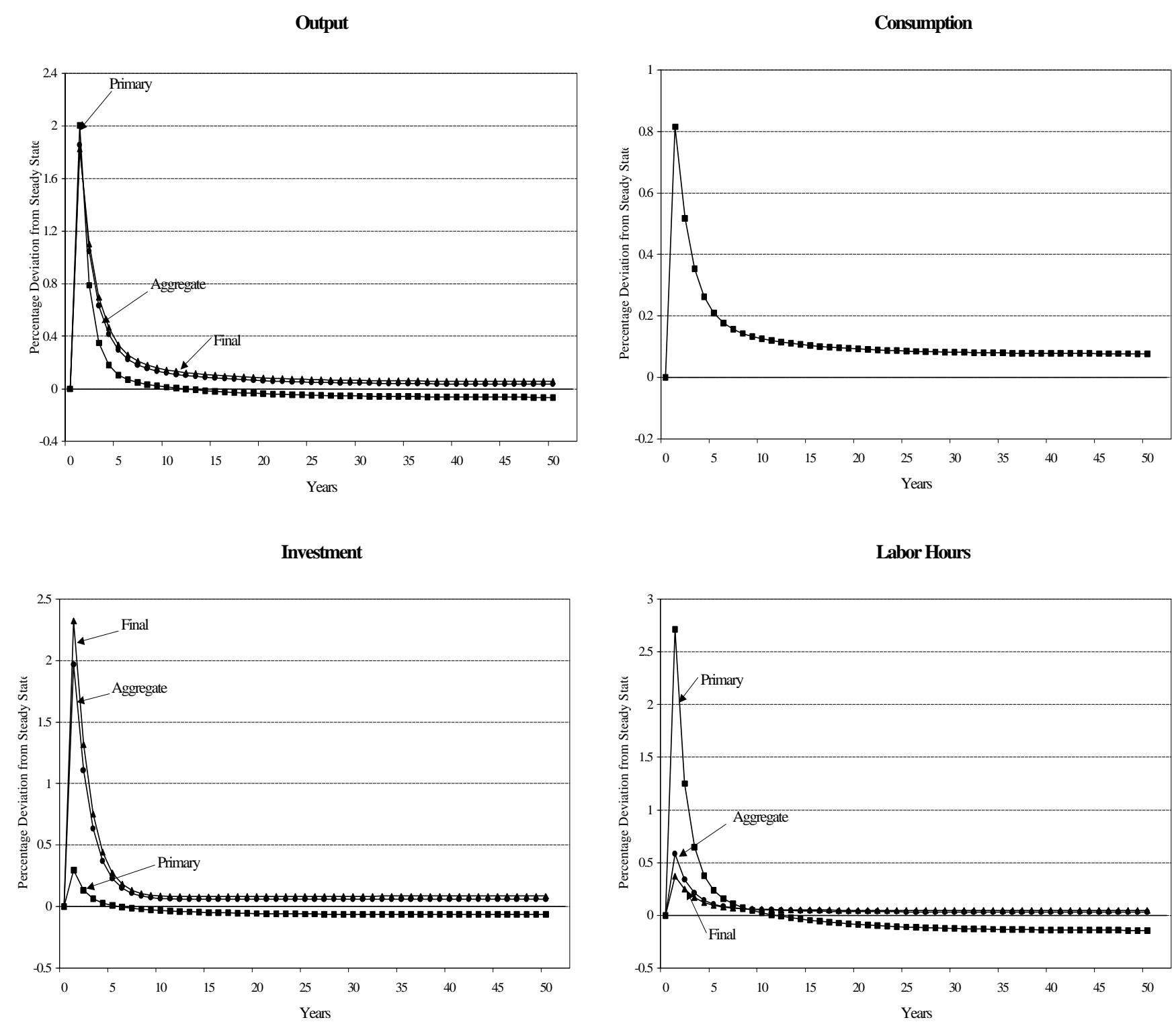

Trade Balance

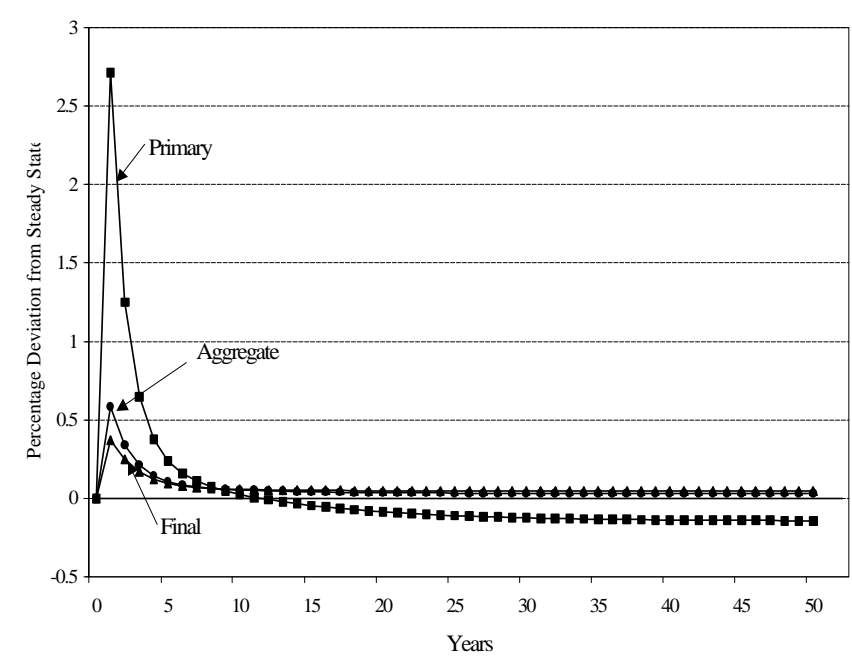

Intermediate Inputs
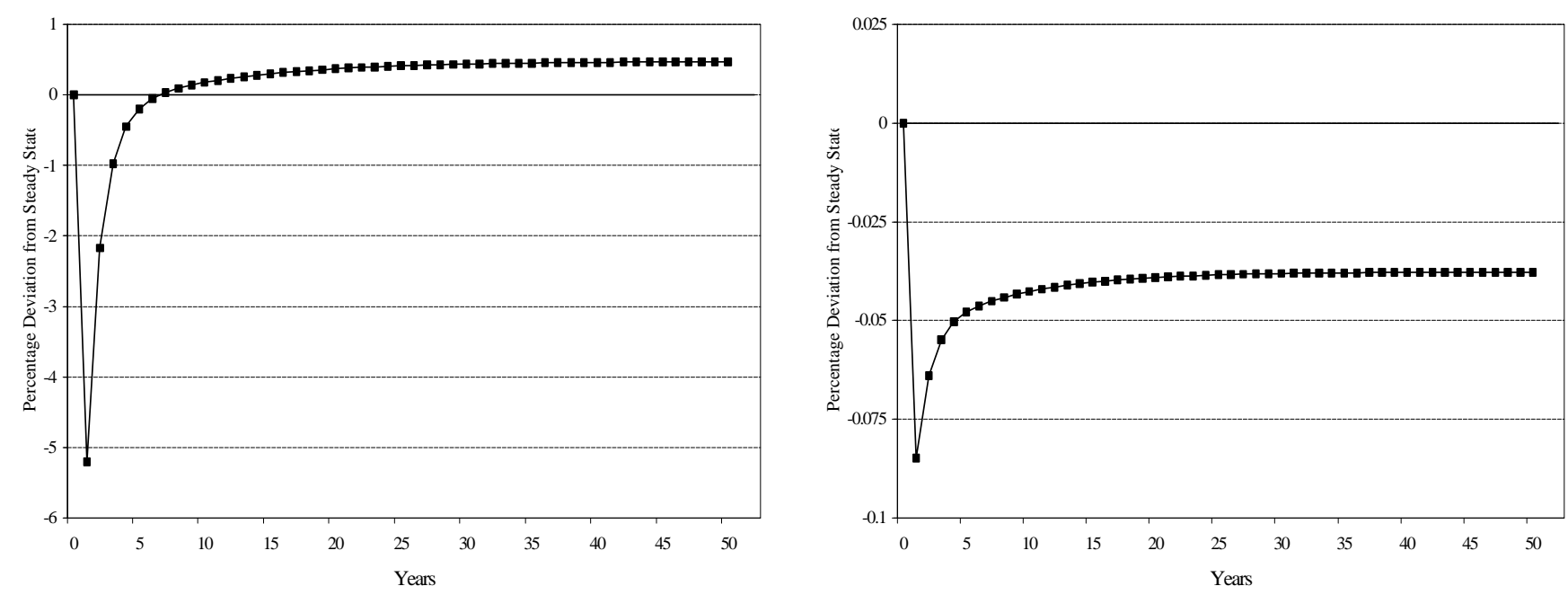
Output

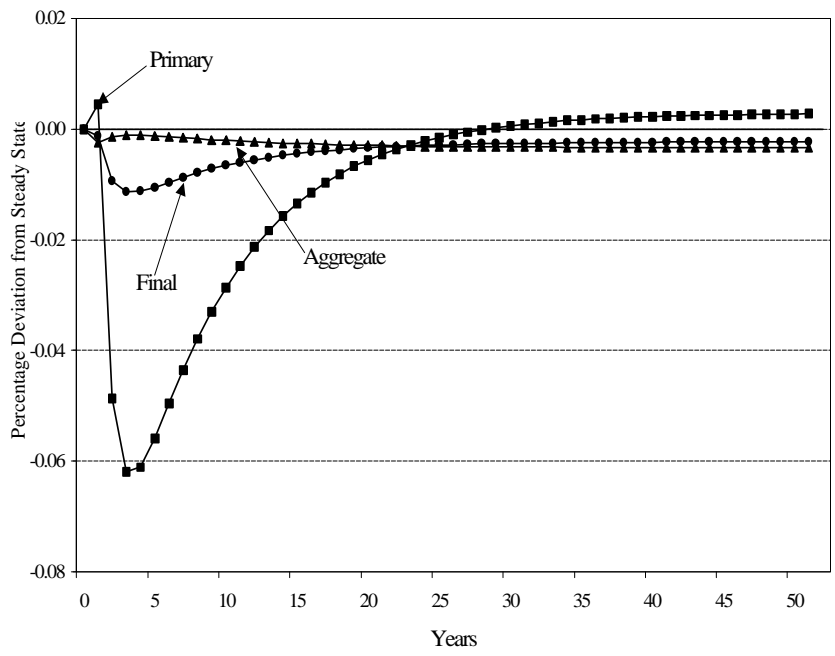

Investment

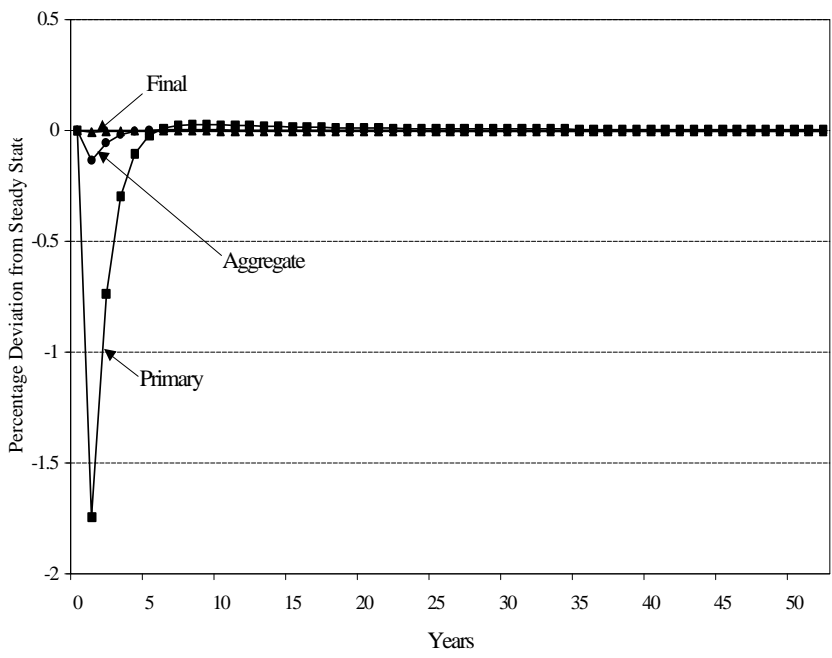

Trade Balance

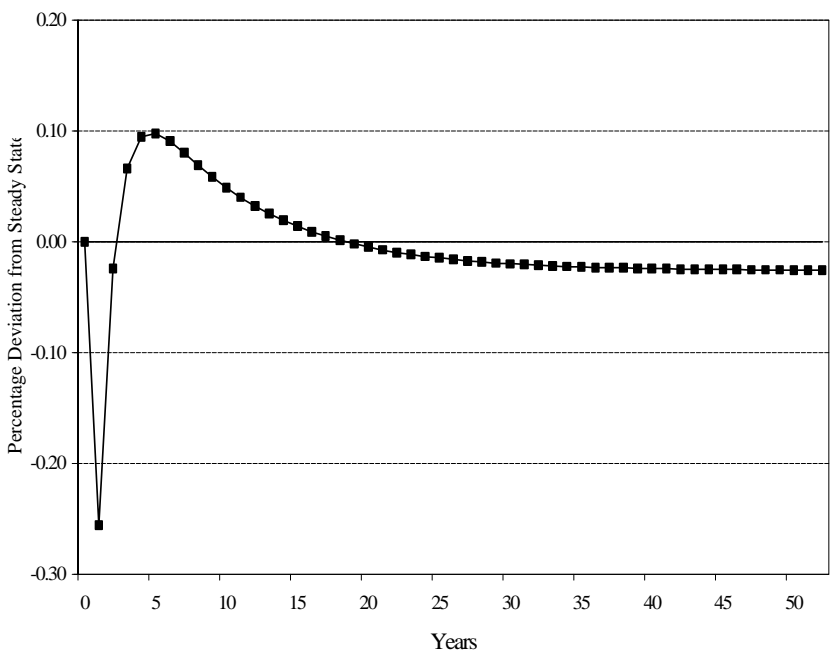

Consumption

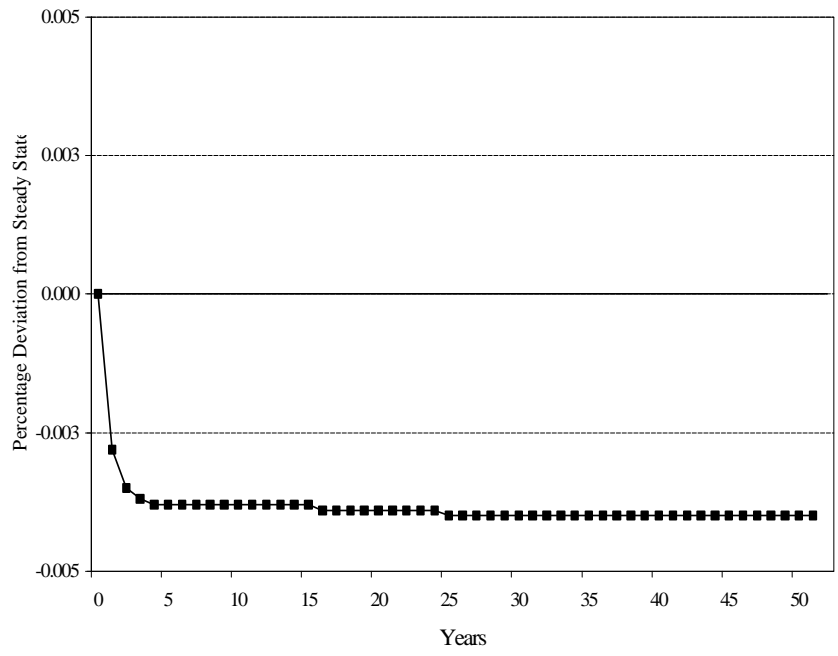

Labor Hours

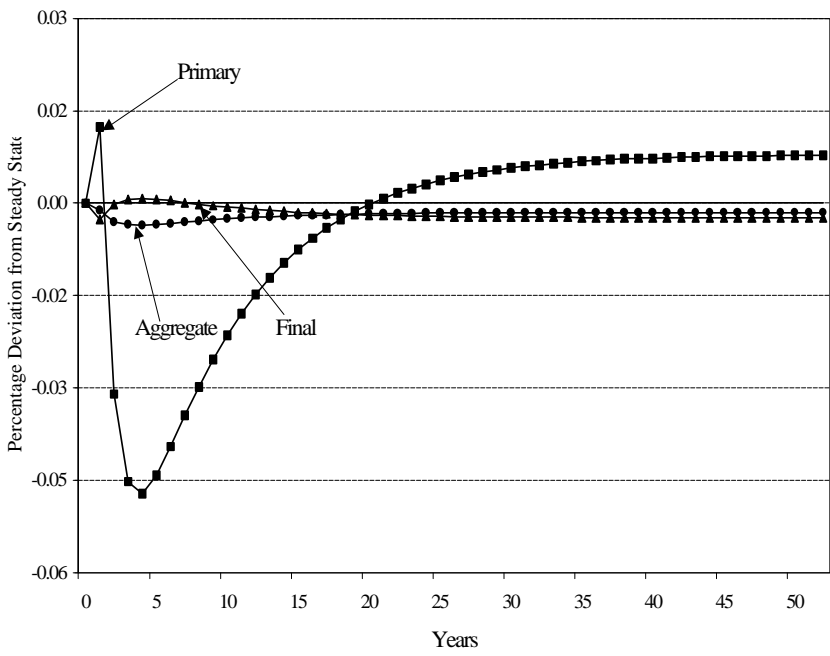

Intermediate Inputs

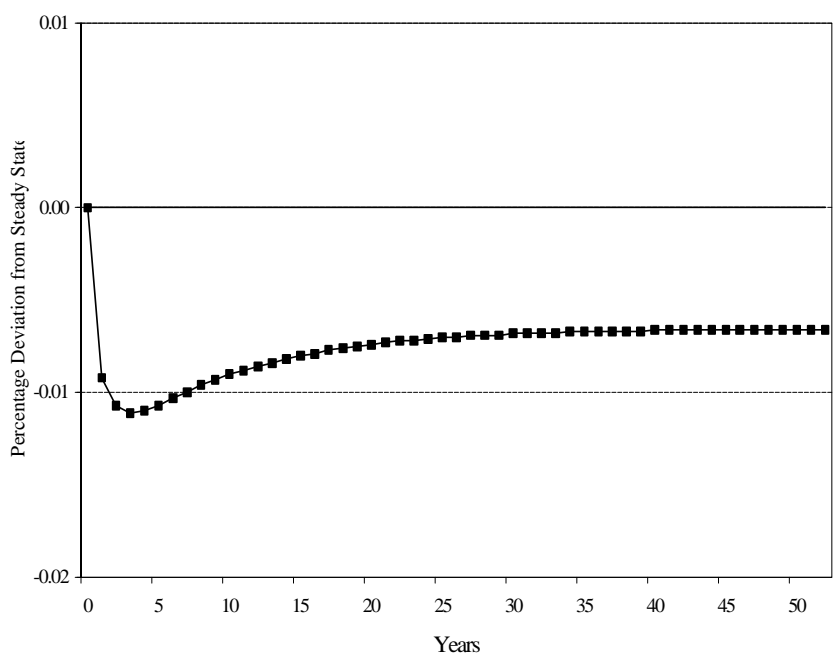



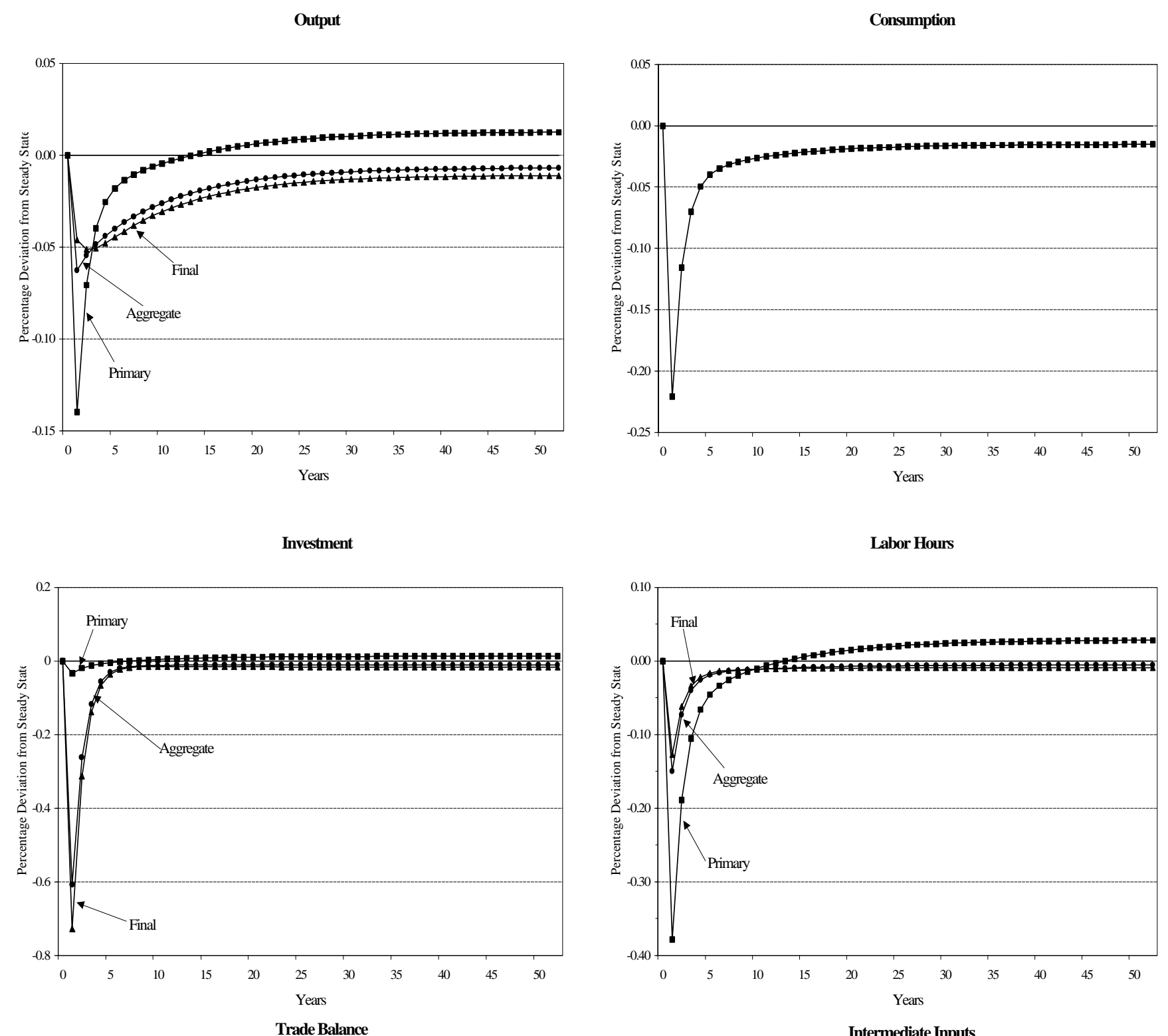

Intermediate Inputs
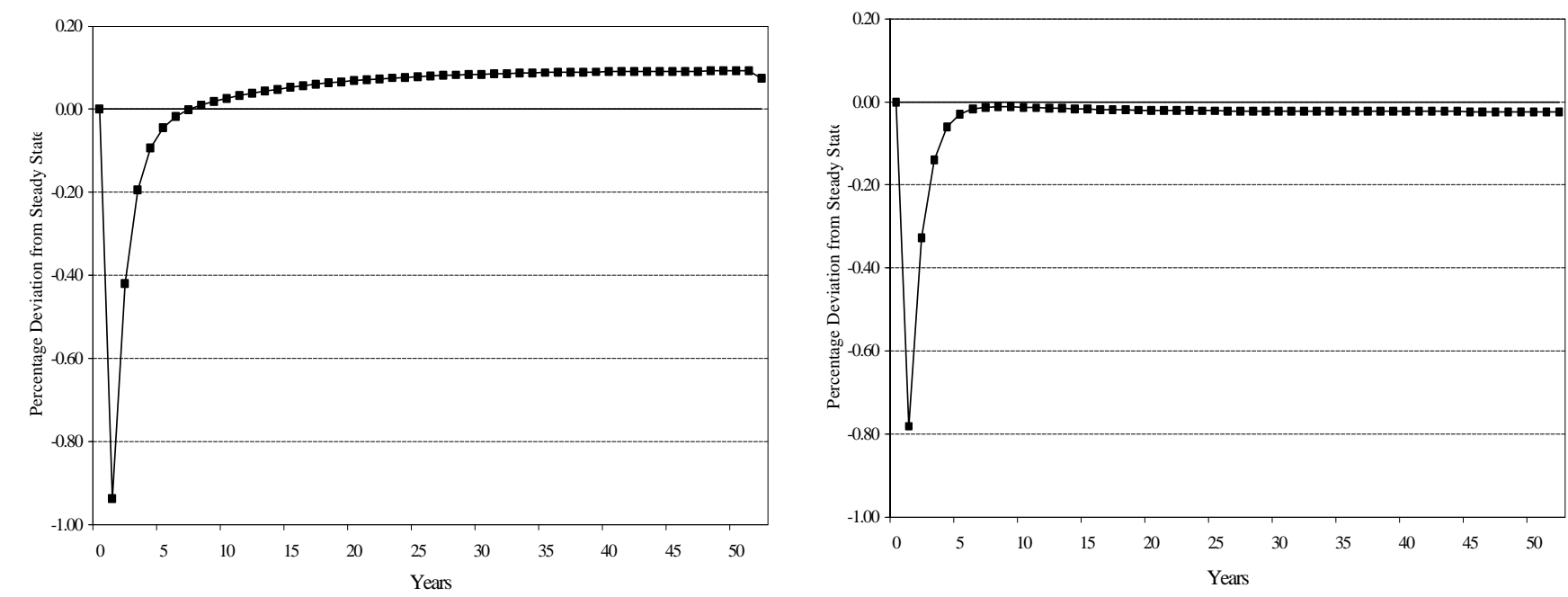


\section{Appendix A:}

\section{A1. Solution of the Model}

We solve the representative household's problem by using the method of log-linear approximation. We briefly explain the major steps of our solution below:

(1) By substituting (9) into (3) and rearranging the terms, it is possible to rewrite the optimization problem as

$$
\begin{array}{lc} 
& \max . \quad U(c, l) \\
\left(\lambda_{1 t}\right): & c_{t}+i_{t}^{f}=y_{t}^{f} \\
\left(\lambda_{2 t}\right): & p_{t}^{k} i_{t}^{p}+p_{t}^{v} v_{t}+A_{t+1}=y_{t}^{p}+\left(1+r_{t}\right) A_{t} \\
\left(\gamma_{1 t}\right): & k_{t+1}^{f}=(1-\delta) k_{t}^{f}+\phi_{f}\left(\frac{i_{t}^{f}}{k_{t}^{f}}\right) k_{t}^{f} \\
\left(\gamma_{2 t}\right): & k_{t+1}^{p}=(1-\delta) k_{t}^{p}+\phi_{p}\left(\frac{i_{t}^{p}}{k_{t}^{p}}\right) k_{t}^{p}
\end{array}
$$

where $\lambda_{1 t}, \lambda_{2 t}, \gamma_{1 t}$, and $\gamma_{2 t}$ are the Lagrange multipliers.

(2) Find the first order conditions of the problem:

$$
\begin{array}{lc}
\left(c_{t}\right): & \frac{\partial U}{\partial c_{t}}-\lambda_{1 t}=0 \\
\left(l_{t}\right): & \frac{\partial U}{\partial l_{t}}-\lambda_{1 t} \frac{\partial y_{t}^{f}}{\partial l_{t}}=0 \\
\left(i_{t}^{f}\right): & -\lambda_{1 t}+\gamma_{1 t} \frac{\partial \phi}{\partial i_{t}^{f}}=0 \\
\left(i_{t}^{p}\right): & -\lambda_{2 t} p_{t}^{k}+\gamma_{2 t} \frac{\partial \phi}{\partial i_{t}^{p}}=0 \\
\left(v_{t}\right): & -\lambda_{2 t} p_{t}^{v}+\lambda_{1 t} \frac{\partial y_{t}^{f}}{\partial v_{t}}=0 \\
\left(n_{t}^{p}\right): & \lambda_{2 t} \frac{\partial y_{t}^{p}}{\partial n_{t}^{p}}+\lambda_{1 t} \frac{\partial y_{t}^{f}}{\partial n_{t}^{p}}=0 \\
\left(k_{t+1}^{f}\right): & -\gamma_{1 t}+\beta E_{t}\left\{\lambda_{1 t+1} \frac{\partial y_{t+1}^{f}}{\partial k_{t+1}^{f}}+\gamma_{1 t+1}\left[\left(1-\delta_{f}\right)+\phi \frac{\partial \phi}{\partial k_{t+1}^{f}} k_{t+1}^{f}\right]\right\}=0 \\
\left(k_{t+1}^{p}\right): & -\gamma_{2 t}+\beta E_{t}\left\{\lambda_{2 t+1} \frac{\partial y_{t+1}^{p}}{\partial k_{t+1}^{p}}+\gamma_{2 t+1}\left[\left(1-\delta_{p}\right)+\phi \frac{\partial \phi}{\partial k_{t+1}^{p}} k_{t+1}^{p}\right]\right\}=0 \\
\left(A_{t+1}\right): & -\lambda_{2 t}+\beta E_{t}\left\{\lambda_{2 t+1}\left(1+r_{t+1}\right)\right\}=0
\end{array}
$$

and the transversality conditions

$$
E_{0} \lim _{t \rightarrow \infty} \beta \gamma_{j t} k_{t+1}^{j}=0 \quad j=f, p
$$




$$
E_{0} \lim _{t \rightarrow \infty} \beta \lambda_{2 t} A_{t+1}=0
$$

(3) In order to find the steady state of the model, use the resource constraints and first order conditions and assume that

$$
x_{t-1}=x_{t}=x_{t+1} \quad, \forall t
$$

for any variable $x$. It is also assumed that there is no adjustment cost at the steady state.

(4) Transform the non-linear system of equations, which are the resource constraints and the first order conditions, into a linear system. This amounts to taking first order Taylor series approximation of each system equation around the deterministic steady state of the model. The resulting linear system expresses each variable in terms of percentage deviations from the steady state (for any variable $x$, the percentage deviation of $x_{t}$ from the deterministic steady state is denoted by $\hat{x}_{t}$ which is equal to $\ln \left(x_{t} / x\right)$ ).

(5) Obtain the solution of the linear system by utilizing stochastic control theory. The solution can be written as

$$
\begin{gathered}
S_{t+1}=M_{1}^{1} S_{t}+M_{1}^{2} \varepsilon_{t+1} \\
C_{t}=M_{2}^{1} S_{t}
\end{gathered}
$$

where $S_{t}$ is the vector of the state variables and $C_{t}$ is the vector of the control variables given as

$$
\begin{aligned}
S_{t}^{\prime} & =\left[\begin{array}{llllllll}
\hat{k}_{t}^{f} & \hat{k}_{t}^{p} & \hat{A}_{t} & \hat{p}_{t}^{k} & \hat{p}_{t}^{v} & \hat{r}_{t} & \hat{z}_{t}^{f} & \hat{z}_{t}^{p}
\end{array}\right] \\
C_{t}^{\prime} & =\left[\begin{array}{llll}
\hat{c}_{t} \hat{l}_{t} \hat{n}_{t}^{p} & \hat{v}_{t} \hat{i}_{t}^{f} & \hat{i}_{t}^{p} & \hat{\lambda}_{1 t}
\end{array}\right]
\end{aligned}
$$

(6) Simulate the above system by feeding exogenous shocks. Calculate the relevant business cycle statistics after extracting the trend from the artificial data using the HP(100) filter.

(7) Find the response of the model variables to the exogenous shocks by using the solution above.

\section{A2. The Data Sources and Definitions}

\section{A. Sectoral GDP}

All sectoral GDP data in the Tables 1a-1c are taken from the World Bank World Tables (1994 with Supplement). This source provides data on sectoral value added, price levels, and international trade. The sectoral classifications of this data set are based on the International Standard Industry Classification (ISIC). All of the countries in the sample are non-oil exporting economies. Our main criteria for selecting the countries in the sample is the availability of the data. The sample data are annual observations from 1970 to 1992 and expressed in current prices (base year=1980). All data are transformed in per capita terms. Below we define all relevant series that are used in our study. The names of the model variables are given in parenthesis:

$\mathbf{y}\left(y^{p}+y^{f}\right):$ GDP at factor cost $=$ the sum of the value added in the agriculture, industry, and services sectors

ag $\left(y^{p}\right)$ : agriculture value added $=$ agricultural and livestock production and services, fishing, hunting, logging, and forestry

man: manufacturing value added = all manufacturing activities

ind: industry value-added= mining and quarrying; manufacturing; construction; and electricity, gas and water. 
ser: services value added=all service activities (transport, storage, communications; wholesale and retail trade; banking, insurance, and real estate, etc.)

con $(c)$ : consumption $=$ total private consumption

$\operatorname{inv}\left(i^{p}+i^{f}\right):$ investment $=$ total fixed investment

emp: employment $=$ the average number of employees or persons engaged in manufacturing activity during the year

exp: value of exports

imp: value of imports

tb: exp-imp

pop: total population (midyear estimates)

The data on decomposition of GDP and international trade in the Tables 1a-1c are taken from the various issues of the Handbook of International Trade and Development Statistics (Tables 4.1 and 4.2 in the source). The sectoral classifications of this data set are based on the Standard International Trade Classification (SITC). Below we define the relevant series and provide the names of some representative commodities in each group for descriptive purposes. SITC codes are also presented in parenthesis.

food $(0+1+22+4)$ : all food items (live animals chiefly for food, vegetables, rice, wheat, animal and vegetable oils, beverages and tobacco, etc.)

agricul. (2 less $(22+27+28)$ ): agricultural raw materials (crude materials except fuels, silk, cotton, etc.)

metals $(27+28+68)$ : ores and metals (fertilizers, base metals, copper, nickel, zinc, tin, lead, etc.)

primary : food, agriculture, and metals.

manuf. (5 to 8 less 68): manufactured goods (chemicals such as medicinal and pharmaceutical products; manufactured goods classified chiefly by material such as leather, wood manufactures, paper; machinery and transport equipment such as food processing machines, engines and motors, road motor vehicles etc.)

mach. (7) : machinery and equipment

inter. (5+6+8 less 68): all manufactured goods less machinery

fuels (3) : mineral fuels, lubricants and related materials (gas, coal, oils etc.)

\section{B. Export Concentration and Diversification Indices}

The data in Table $1 \mathrm{~b}$ are taken from from the various issues of the Handbook of International Trade and Development Statistics (Table 4.9 in the source). The concentration index, namely Gini-Hirschman coefficient, is calculated by using the formula

$$
C_{j}=100 * \frac{\sqrt{\sum_{i=1}^{M}\left(y_{i} / Y\right)^{2}}-\sqrt{1 / M}}{1-\sqrt{1 / M}}
$$

where $j=$ country index

$y_{i}=$ value of exports of commodity $i$

$Y=\sum_{i=1}^{M} y_{i}$ 
$M=$ number of products at the three digit SITC level for the relevant year. The index ranges 0 to 100. A higher value of this coefficient indicates a higher degree of export concentration. For an extensive discussion of this index, see Michaely (1984).

\section{Debt Indicators}

The debt data in the Table 1d come from the two different sources, the World Bank World Debt Tables (1992-1993). This set contains reported data on total external debt of all low and middle income countries. We provide the definitions of each variable below. The names of the variables in the World Debt Tables are given in parenthesis:

gnp (GNP): gross national product

ed (EDT): total external debt consists of public and publicly guaranteed long-term debt, private nonguaranteed long-term debt, the use of IMF credit, and estimated short-term debt.

in (INT): total interest payments are actual amounts of interest paid in foreign currency, goods, or services.

exp (XGS): exports of goods and services including workers' remittances.

td (TDS): total debt service which is the sum of principal repayments and interest payments actually made.

sh (short-term): short term external debt is defined as debt that has an original maturity of one year or less.

\section{World Prices}

The data in the Table 4 is taken from the following sources: CITIBASE and the World Bank World Tables (1994). The data on LIBOR and export unit value index of non-fuel commodity exporting developing countries are from the International Financial Statistics. The definitions of these variables are given below. The CITIBASE names of the variables are in parenthesis:

pcap (pwfpsa): producer price index of capital equipment. Capital equipment includes machinery and equipment (agricultural, construction, metal cutting, industrial handling, office and store machines and equipment, etc.).

pint (pwimsa): producer price index of intermediate materials, supplies and components. Intermediate materials include steel mill products, hardware, heating equipment, mechanical power transmission equipment, etc.).

pexp : export price index measures changes in the aggregate price level of a country's merchandise exports over time $(1987=100)$.

tot : terms of trade index which is the relative price of export prices compared with import prices, calculated as the ratio of a country's index of average export price to the average import price index.

We deflate these prices (pcap and pint) by using the unit value index of imports for developing countries. Then, the relative prices are calculated as

$$
\begin{gathered}
p^{k}=p c a p / p \exp \\
p^{v}=p \text { int } / p \exp
\end{gathered}
$$

The data used to plot the Figure 1 are taken from two different sources: The series of non-fuel commodity prices and terms of trade are from the International Financial Statistics. Prices of agricultural commodities are taken from the World Bank Commodity Markets and the Developing Countries. 


\section{Appendix B:}

\begin{tabular}{|c|c|c|c|c|c|c|c|c|c|c|c|c|}
\hline \multicolumn{13}{|c|}{$\begin{array}{c}\text { Table A1 } \\
\text { Decomposition of GDP } \\
\text { (in percent) }\end{array}$} \\
\hline \multicolumn{8}{|c|}{ Expenditure Shares } & \multicolumn{5}{|c|}{ Industrial Structure } \\
\hline Country & Gvt. & Con. & Inv. & Exp. & Imp. & T.V. & T.B. & Agr. & Ind. & Man. & Con. & Ser. \\
\hline \multicolumn{13}{|c|}{ African Countries } \\
\hline Burundi & 14.0 & 84.7 & 12.0 & 10.0 & 19.7 & 29.7 & -9.7 & 55.3 & 11.7 & 14.3 & 3.0 & 30.0 \\
\hline Cape Verde & 13.7 & 109.7 & 27.7 & 21.0 & 72.0 & 93.0 & -51.0 & 19.0 & 8.3 & 5.3 & 15.3 & 56.7 \\
\hline Egypt & 17.0 & 68.0 & 23.7 & 24.0 & 33.0 & 57.0 & -9.0 & 19.7 & 23.7 & 15.3 & 3.7 & 52.7 \\
\hline Gambia & 16.3 & 88.7 & 27.0 & 29.3 & 62.3 & 91.6 & -33.0 & 31.0 & 6.0 & 5.3 & 5.7 & 57.3 \\
\hline Ghana & 11.7 & 81.0 & 10.7 & 15.3 & 19.0 & 34.3 & -3.7 & 41.3 & 11.3 & 9.0 & 2.7 & 44.7 \\
\hline Guin. Bis. & 20.7 & 85.0 & 23.7 & 8.3 & 37.3 & 45.7 & -29.0 & 45.3 & 12.3 & 11.7 & 10.0 & 37.5 \\
\hline Kenya & 18.0 & 62.0 & 26.0 & 27.3 & 33.3 & 60.6 & -6.0 & 29.3 & 12.0 & 10.0 & 6.3 & 52.3 \\
\hline Liberia & 14.0 & 57.3 & 15.7 & 55.3 & 42.7 & 98.0 & 12.7 & 28.3 & 25.3 & 5.7 & 3.7 & 42.0 \\
\hline Madagascar & 16.3 & 74.3 & 14.7 & 17.3 & 23.0 & 40.3 & -5.7 & 35.0 & 13.7 & 11.7 & 4.0 & 47.3 \\
\hline Malavi & 16.7 & 75.0 & 22.3 & 23.3 & 37.7 & 61.0 & -14.3 & 39.0 & 13.0 & 10.3 & 3.3 & 44.3 \\
\hline Mauritania & 18.0 & 68.7 & 22.3 & 41.3 & 50.7 & 92.0 & -9.3 & 30.7 & 24.7 & 6.7 & 6.0 & 38.3 \\
\hline Mauritius & 12.7 & 67.0 & 26.7 & 56.3 & 62.3 & 118.7 & -6.0 & 15.3 & 18.7 & 16.7 & 6.3 & 60.0 \\
\hline Morocco & 15.0 & 69.0 & 21.7 & 19.3 & 25.0 & 44.3 & -5.7 & 19.3 & 25.3 & 17.3 & 5.0 & 50.0 \\
\hline Seychelles & 23.0 & 57.3 & 34.7 & 46.0 & 61.0 & 107.0 & -15.0 & 8.7 & 7.7 & 6.7 & 8.3 & 75.3 \\
\hline Sierra Lione & 8.7 & 82.0 & 15.3 & 26.3 & 32.7 & 59.0 & -6.3 & 31.3 & 20.3 & 8.3 & 3.0 & 42.3 \\
\hline Sudan & 14.7 & 77.3 & 16.0 & 10.3 & 18.3 & 28.7 & -8.0 & 36.7 & 10.0 & 8.3 & 4.7 & 49.0 \\
\hline Swaziland & 20.0 & 50.7 & 39.0 & 75.0 & 84.3 & 159.3 & -9.3 & 20.0 & 24.0 & 17.7 & 3.3 & 52.3 \\
\hline Tanzania & 13.0 & 73.7 & 29.7 & 18.0 & 33.7 & 51.7 & -15.7 & 44.3 & 10.7 & 7.7 & 3.7 & 41.3 \\
\hline Tunisia & 16.0 & 64.3 & 25.7 & 35.0 & 41.3 & 76.3 & -6.3 & 15.0 & 22.7 & 12.3 & 5.3 & 57.3 \\
\hline Zaire & 21.3 & 39.7 & 23.0 & 48.7 & 33.0 & 81.7 & 15.7 & 24.3 & 23.7 & 4.0 & 5.0 & 47.0 \\
\hline Zambia & 34.0 & 35.7 & 25.7 & 40.3 & 36.0 & 76.3 & 4.3 & 12.3 & 42.7 & 18.7 & 5.3 & 39.3 \\
\hline Zimbabwe & 19.3 & 60.3 & 20.7 & 29.3 & 29.7 & 59.0 & -0.3 & 15.3 & 32.3 & 22.3 & 3.3 & 49.0 \\
\hline Mean & 17.0 & 69.6 & 22.9 & 30.8 & 40.4 & 71.1 & -9.6 & 28.0 & 18.2 & 11.2 & 5.3 & 48.5 \\
\hline Median & 16.3 & 68.8 & 23.3 & 26.8 & 34.8 & 60.8 & -7.2 & 28.8 & 16.2 & 10.2 & 4.8 & 48.2 \\
\hline \multicolumn{13}{|l|}{$\underline{\text { G7 Countries }}$} \\
\hline Mean & 16.6 & 59.3 & 23.9 & 19.7 & 18.3 & 38.0 & 1.3 & 3.7 & 29.7 & 25.4 & 6.6 & 60.0 \\
\hline Median & 18.0 & 59.0 & 24.3 & 20.3 & 20.3 & 40.7 & 0.7 & 3.7 & 28.0 & 23.8 & 6.3 & 62.0 \\
\hline $\begin{array}{l}\text { Gvt. }=\text { governme } \\
\text { Trade Vol. }=(\text { Exp } \\
\text { electricity }+ \text { gas }+ \\
\text { oil exporting Afr }\end{array}$ & inal ext & liture; & =priv & nal co & ption & nditu & $\mathrm{v} .=\mathrm{grc}$ & omes & vestn & Exp. $=$ & rts; In & $\begin{array}{l}\text { imports } \\
\text { arrying } \\
22 \text { non }\end{array}$ \\
\hline
\end{tabular}




\begin{tabular}{|c|c|c|c|c|c|c|c|c|c|c|c|}
\hline \multicolumn{12}{|c|}{$\begin{array}{c}\text { Table A2 } \\
\text { Decomposition of Exports } \\
\text { (in percent) }\end{array}$} \\
\hline Country & Food & Agr. & Metals & Prima. & Man. & Cap. & Inter. & Fuels & $\begin{array}{l}\text { Total } \\
\text { Inter. }\end{array}$ & $\begin{array}{l}\text { Num. } \\
\text { Exp. }\end{array}$ & $\begin{array}{c}\text { Concen } \\
\text { Index } \\
\end{array}$ \\
\hline \multicolumn{12}{|c|}{ African Countries } \\
\hline$\overline{\text { Burundi }}$ & 78.9 & 6.4 & 3.8 & 89.1 & 1.9 & 0.2 & 1.7 & 0.0 & 1.7 & 12.0 & 80.1 \\
\hline Cape Verde & 71.9 & 2.1 & 8.0 & 81.9 & 8.0 & 4.9 & 3.1 & 0.3 & 3.4 & 15.7 & 43.5 \\
\hline Egypt & 12.5 & 22.7 & 0.3 & 35.5 & 23.5 & 1.4 & 22.1 & 38.6 & 60.8 & 107.0 & 71.9 \\
\hline Gambia & 84.3 & 7.8 & 0.2 & 92.3 & 11.6 & 0.5 & 11.1 & 0.0 & 11.1 & 16.0 & 45.5 \\
\hline Ghana & 65.7 & 7.8 & 16.9 & 90.4 & 4.9 & 0.3 & 4.8 & 1.3 & 6.1 & 44.0 & 64.4 \\
\hline Guine Bis. & 89.7 & 4.9 & 0.4 & 95.0 & 3.4 & 0.7 & 2.8 & 0.3 & 3.1 & 13.7 & 57.6 \\
\hline Kenya & 55.1 & 9.2 & 1.6 & 65.9 & 14.0 & 0.9 & 13.1 & 19.8 & 32.9 & 134.0 & 31.9 \\
\hline Liberia & 5.1 & 25.4 & 55.7 & 86.1 & 11.6 & 0.7 & 11.0 & 2.2 & 13.2 & 31.0 & 58.4 \\
\hline Madagas. & 76.2 & 4.6 & 6.0 & 86.8 & 9.6 & 1.8 & 7.8 & 3.6 & 11.4 & 64.3 & 36.9 \\
\hline Malavi & 89.9 & 4.4 & 0.2 & 94.5 & 4.8 & 0.2 & 4.6 & 0.0 & 4.7 & 33.0 & 55.0 \\
\hline Mauritania & 24.4 & 1.6 & 71.7 & 97.8 & 1.2 & 0.7 & 0.5 & 0.7 & 1.1 & 20.7 & 71.6 \\
\hline Mauritius & 67.2 & 0.2 & 0.0 & 67.5 & 32.4 & 1.9 & 30.6 & 0.0 & 30.6 & 55.0 & 65.1 \\
\hline Morocco & 34.6 & 3.7 & 29.4 & 67.6 & 28.5 & 2.0 & 26.5 & 2.9 & 29.4 & 117.3 & 79.4 \\
\hline Seychelles & 64.0 & 1.1 & 3.0 & 68.2 & 4.1 & 4.1 & 2.5 & 27.4 & 29.9 & 8.0 & 69.9 \\
\hline Sierra Lio. & 21.6 & 2.0 & 31.5 & 55.0 & 42.3 & 0.3 & 42.1 & 3.2 & 45.3 & 25.7 & 51.7 \\
\hline Sudan & 36.7 & 61.6 & 0.4 & 98.7 & 0.6 & 0.2 & 0.6 & 0.3 & 0.9 & 42.0 & 92.2 \\
\hline \multicolumn{12}{|l|}{ Swaziland } \\
\hline Tanzania & 52.4 & 23.3 & 6.9 & 82.6 & 12.9 & 1.0 & 11.8 & 4.3 & 16.1 & 68.7 & 26.8 \\
\hline Tunisia & 16.0 & 2.2 & 8.1 & 26.3 & 41.3 & 3.5 & 37.8 & 32.3 & 70.1 & 128.7 & 69.3 \\
\hline Zambia & 2.0 & 1.0 & 93.4 & 96.4 & 3.4 & 0.3 & 3.1 & 0.1 & 3.2 & 46.0 & 84.2 \\
\hline Zaire & 10.6 & 3.5 & 60.4 & 74.5 & 9.8 & 9.0 & 0.8 & 6.8 & 7.6 & 47.0 & 77.0 \\
\hline Zimbabwe & 36.5 & 8.6 & 21.2 & 66.3 & 31.9 & 2.8 & 29.1 & 1.1 & 30.2 & 111.3 & 29.3 \\
\hline Mean & 47.4 & 9.7 & 20.0 & 77.1 & 14.4 & 1.8 & 12.7 & 6.9 & 19.7 & 54.3 & 60.1 \\
\hline Median & 52.4 & 4.6 & 6.9 & 82.6 & 9.8 & 0.9 & 7.8 & 1.3 & 11.4 & 44.0 & 64.4 \\
\hline \multicolumn{12}{|c|}{ G7 Countries } \\
\hline Mean & 8.9 & 3.2 & 4.6 & 16.7 & 76.8 & 40.7 & 36.2 & 4.5 & 40.7 & 213 & 9.6 \\
\hline Median & 7.3 & 1.6 & 3.6 & 12.8 & 76.9 & 38.5 & 39.4 & 3.5 & 42.9 & 216 & 9.1 \\
\hline $\begin{array}{l}\text { *Agr.= agricul } \\
\text { Inter.= interme } \\
\text { Concen. Index } \\
\text { G7 countries. } \\
\text { Handbook of I } \\
\end{array}$ & $\begin{array}{l}\text { Iral raw } \\
\text { liate inpu } \\
\text { export cc } \\
\text { or most o } \\
\text { ternationa } \\
\end{array}$ & $\begin{array}{l}\text { aterials; } \\
\text { all man } \\
\text { centrati } \\
\text { he cour }\end{array}$ & $\begin{array}{l}\text { rimary }=\mathrm{F} \\
\text { actured ite } \\
\text { index. To } \\
\text { ies in our }\end{array}$ & $\begin{array}{l}\text { od+Agr.+1 } \\
\text { is less ma } \\
\text { et the mea } \\
\text { mple, the }\end{array}$ & are a & $\begin{array}{l}\text { malues, } \\
\text { ges over }\end{array}$ & $\begin{array}{l}\text { d goods } \\
\text { r+Fuels; } \\
\text { se the da } \\
\text { years } 19\end{array}$ & $\begin{array}{l}\text { ap.=cap } \\
\text { mber E } \\
\text { of } 22 \text { no } \\
1980,\end{array}$ & $\begin{array}{l}\text { goods }=\mathrm{n} \\
\text { number } \\
\text { lexporti } \\
990 . \mathrm{Th}\end{array}$ & $\begin{array}{l}\text { inery an } \\
\text { Commodi } \\
\text { African e } \\
\text { urce of }\end{array}$ & $\begin{array}{l}\text { equipment } \\
\text { nomies and } \\
\text { data is the }\end{array}$ \\
\hline
\end{tabular}




\begin{tabular}{|c|c|c|c|c|c|c|c|c|c|}
\hline \multicolumn{10}{|c|}{$\begin{array}{c}\text { Table A3 } \\
\text { Decomposition of Imports } \\
\text { (in percent) }\end{array}$} \\
\hline Country & Food & Agr. & Metals & Primary & Man. & Cap. & Inter. & Fuels & $\begin{array}{l}\text { Total } \\
\text { Inter. }\end{array}$ \\
\hline \multicolumn{10}{|c|}{ African Countries } \\
\hline Burundi & 17.6 & 4.9 & 1.8 & 24.3 & 62.2 & 25.1 & 37.1 & 11.6 & 48.7 \\
\hline Cape Verde & 46.5 & 1.3 & 0.0 & 47.8 & 29.6 & 9.9 & 19.6 & 12.7 & 32.3 \\
\hline Egypt & 29.0 & 7.2 & 2.3 & 38.6 & 57.0 & 25.6 & 31.4 & 4.4 & 35.8 \\
\hline Gambia & 26.4 & 1.9 & 0.5 & 28.8 & 62.1 & 19.0 & 43.1 & 7.9 & 50.9 \\
\hline Ghana & 14.8 & 1.9 & 1.7 & 18.4 & 63.7 & 26.9 & 36.8 & 16.4 & 53.2 \\
\hline Guinea Bus. & 27.6 & 0.2 & 1.2 & 29.0 & 60.9 & 26.0 & 34.8 & 9.4 & 44.3 \\
\hline Kenya & 7.6 & 2.0 & 1.8 & 11.4 & 66.0 & 34.1 & 31.9 & 21.3 & 53.2 \\
\hline Liberia & 19.5 & 4.2 & 3.5 & 27.3 & 64.6 & 26.8 & 37.8 & 7.8 & 45.6 \\
\hline Madagascar & 10.7 & 1.9 & 0.9 & 13.6 & 73.2 & 32.4 & 40.8 & 13.1 & 53.9 \\
\hline Malavi & 10.7 & 1.6 & 1.4 & 13.6 & 75.0 & 30.9 & 44.1 & 11.0 & 55.1 \\
\hline Mauritania & 27.9 & 1.1 & 0.5 & 29.5 & 59.2 & 33.3 & 25.9 & 9.9 & 35.8 \\
\hline Mauritius & 25.1 & 2.6 & 1.0 & 28.7 & 61.4 & 18.9 & 42.5 & 9.7 & 52.2 \\
\hline Morocco & 16.8 & 6.9 & 4.0 & 27.6 & 57.1 & 20.2 & 36.8 & 15.3 & 52.2 \\
\hline Seychelles & 23.3 & 1.5 & 0.8 & 25.6 & 56.6 & 25.2 & 31.3 & 16.9 & 48.3 \\
\hline Sierra Lione & 22.5 & 1.1 & 0.8 & 24.4 & 64.4 & 27.4 & 37.0 & 10.1 & 47.1 \\
\hline Sudan & 22.2 & 1.8 & 0.7 & 24.7 & 61.5 & 25.8 & 35.8 & 13.4 & 49.1 \\
\hline Swaziland & na & na & na & na & na & na & na & na & na \\
\hline Tanzania & 11.6 & 1.0 & 1.9 & 14.4 & 71.9 & 38.0 & 33.9 & 13.5 & 47.3 \\
\hline Tunisia & 17.4 & 4.5 & 4.0 & 25.8 & 62.5 & 25.9 & 36.6 & 11.5 & 48.1 \\
\hline Zambia & 7.6 & 1.0 & 2.1 & 10.7 & 72.3 & 35.8 & 36.6 & 16.7 & 53.2 \\
\hline Zaire & 17.8 & 1.2 & 1.5 & 20.5 & 70.9 & 32.9 & 38.0 & 8.2 & 46.2 \\
\hline Zimbabwe & 3.1 & 2.6 & 1.9 & 7.6 & 76.9 & 44.2 & 32.7 & 12.3 & 45.0 \\
\hline Mean & 19.3 & 2.5 & 1.6 & 23.4 & 63.3 & 27.8 & 35.5 & 12.0 & 47.5 \\
\hline Median & 17.8 & 1.9 & 1.5 & 24.7 & 62.5 & 26.8 & 36.6 & 11.6 & 48.3 \\
\hline \multicolumn{10}{|c|}{ G7 Countries } \\
\hline Mean & 12.6 & 5.3 & 7.1 & 25.0 & 57.1 & 26.9 & 30.3 & 16.4 & 46.6 \\
\hline Median & 13.6 & 4.6 & 7.2 & 25.5 & 60.0 & 24.1 & 30.2 & 16.1 & 48.1 \\
\hline
\end{tabular}




\begin{tabular}{|c|c|c|c|c|c|c|c|}
\hline \multicolumn{8}{|c|}{$\begin{array}{c}\text { Table A4 } \\
\text { Debt Indicators } \\
\text { (in percent) } \\
\end{array}$} \\
\hline Country & ED/GNP & IN/GNP & ED/EXP & TD/EXP & IN/EXP & SH/EXP & SH/ED \\
\hline Burundi & 49.4 & 0.9 & 554.4 & 26.4 & 9.6 & 24.1 & 4.4 \\
\hline Cape Verde & 34.4 & 0.5 & 76.3 & 2.8 & 1.1 & 1.3 & 1.7 \\
\hline Egypt & 92.0 & 3.8 & 222.9 & 18.0 & 9.2 & 38.8 & 17.4 \\
\hline Gambia & 88.7 & 2.8 & 214.1 & 14.4 & 6.5 & 22.8 & 10.7 \\
\hline Ghana & 47.3 & 1.5 & 252.3 & 24.7 & 7.6 & 22.3 & 8.9 \\
\hline Guine Bis. & 198.6 & 2.1 & 1575.7 & 28.2 & 18.5 & 27.6 & 1.8 \\
\hline Kenya & 70.2 & 4.0 & 262.7 & 33.2 & 14.9 & 30.5 & 11.6 \\
\hline Liberia & 111.6 & 2.1 & 253.0 & 6.2 & 4.2 & 43.0 & 17.0 \\
\hline Madagascar & 87.8 & 3.0 & 515.9 & 33.1 & 17.9 & 70.4 & 13.7 \\
\hline Malavi & 79.6 & 3.5 & 303.9 & 25.7 & 13.1 & 27.3 & 9.0 \\
\hline Mauritania & 174.3 & 4.1 & 371.5 & 23.8 & 8.8 & 35.7 & 9.6 \\
\hline Mauritius & 39.9 & 2.5 & 67.2 & 8.8 & 4.3 & 5.2 & 7.8 \\
\hline Morocco & 74.0 & 4.0 & 263.4 & 27.6 & 14.7 & 13.0 & 5.0 \\
\hline Seychelles & 57.2 & 14.6 & 78.4 & 22.6 & 20.1 & 36.7 & 46.9 \\
\hline Sierra Lione & 95.1 & 1.3 & 454.0 & 16.6 & 5.7 & 114.6 & 25.3 \\
\hline Sudan & 126.3 & 1.2 & 1159.5 & 15.7 & 8.4 & 243.5 & 21.0 \\
\hline Swaziland & 33.8 & 1.6 & 39.1 & 4.9 & 1.9 & 1.7 & 4.5 \\
\hline Tanzania & 173.6 & 2.7 & 779.1 & 33.6 & 13.8 & 65.4 & 8.4 \\
\hline Tunisia & 53.4 & 3.4 & 111.1 & 19.3 & 7.1 & 6.7 & 6.1 \\
\hline Zaire & 73.1 & 2.0 & 321.6 & 18.9 & 8.7 & 22.5 & 7.0 \\
\hline Zambia & 165.7 & 3.2 & 366.1 & 20.1 & 7.2 & 69.2 & 18.9 \\
\hline Zimbabwe & 32.3 & 1.8 & 102.3 & 13.5 & 5.7 & 15.2 & 14.9 \\
\hline Mean & 89.0 & 3.0 & 379.3 & 19.9 & 9.5 & 42.6 & 12.3 \\
\hline Median & 76.8 & 2.6 & 263.0 & 19.7 & 8.6 & 27.5 & 9.3 \\
\hline
\end{tabular}




\section{Properties of Macroeconomic Fluctuations*}

Volatility

\begin{tabular}{|c|c|c|c|c|c|c|c|c|c|c|c|c|}
\hline Country & $\sigma_{\mathbf{y}}$ & $\sigma_{\text {ind }+ \text { ser }}$ & $\sigma_{\mathrm{agr}}$ & $\sigma_{\text {ind }}$ & $\sigma_{\operatorname{man}}$ & $\sigma_{\text {ser }}$ & $\sigma_{\mathrm{c}}$ & $\sigma_{\mathrm{i}}$ & $\sigma_{\text {emp }}$ & $\sigma_{\mathrm{tb}}$ & $\sigma_{\exp }$ & $\sigma_{\text {imp }}$ \\
\hline Burundi & 6.00 & 6.01 & 6.66 & 14.59 & 2.77 & 3.96 & 6.35 & 10.75 & 7.56 & 16.69 & 13.23 & 8.18 \\
\hline Cape & 2.17 & 2.93 & 10.57 & 7.66 & 18.99 & 3.76 & 9.28 & 10.73 & na & 35.04 & 36.09 & 14.45 \\
\hline Egypt & 3.07 & 4.65 & 1.65 & 7.05 & na & 5.30 & 4.07 & 10.00 & 2.18 & 10.54 & 8.00 & 8.69 \\
\hline Gambia & 4.62 & 4.90 & 10.60 & 10.48 & 58.38 & 5.00 & 17.31 & 15.05 & 17.58 & 22.53 & 16.41 & 18.89 \\
\hline Ghana & 4.81 & 5.96 & 6.39 & 11.56 & 14.03 & 5.01 & 9.38 & 17.12 & 11.80 & 19.75 & 16.36 & 23.01 \\
\hline GuBis & 5.31 & 4.29 & 10.34 & 13.93 & na & 10.65 & 16.28 & na & na & 24.62 & 18.53 & 12.53 \\
\hline Kenya & 4.16 & 4.95 & 3.62 & 8.35 & 7.11 & 3.94 & 9.04 & 10.29 & 4.33 & 12.19 & 5.23 & 14.47 \\
\hline Liberia & 2.70 & 3.24 & 3.23 & 5.10 & 10.26 & 5.37 & 10.56 & na & na & 11.40 & 7.76 & 7.28 \\
\hline Mada & 3.01 & 4.17 & 3.03 & 8.28 & na & 3.98 & 4.65 & na & 6.75 & 10.42 & 11.10 & 14.94 \\
\hline Malavi & 3.69 & 3.79 & 7.73 & 4.64 & 2.75 & 4.25 & 5.74 & 19.79 & na & 15.25 & 9.18 & 13.89 \\
\hline Maurita & 2.83 & 4.75 & 8.55 & 7.19 & 6.11 & 6.79 & 10.18 & 23.37 & na & 20.02 & 13.18 & 16.68 \\
\hline Maurus & 5.22 & 6.52 & 10.96 & 8.65 & 7.27 & 6.04 & 9.21 & 15.75 & 12.41 & 11.66 & 9.77 & 14.78 \\
\hline Morocco & 2.76 & 2.21 & 13.39 & 3.09 & 2.25 & 2.81 & 3.57 & 15.46 & 6.22 & 13.68 & 6.65 & 10.55 \\
\hline Seych & 6.84 & 7.34 & 6.13 & 48.41 & 8.48 & 6.99 & na & 12.02 & na & 17.94 & 14.53 & 8.08 \\
\hline SLione & 2.92 & 6.75 & 6.92 & 7.08 & 13.69 & 9.62 & 7.11 & 20.65 & na & 20.73 & 12.77 & 20.71 \\
\hline Sudan & 7.03 & 7.89 & 9.47 & 7.58 & 7.24 & 8.64 & 9.17 & 22.18 & na & 19.48 & 14.11 & 19.35 \\
\hline Swazi & 5.03 & 5.30 & 8.16 & 7.85 & 11.88 & 5.66 & na & na & 6.29 & 15.13 & 13.58 & 8.54 \\
\hline Tanza & 2.66 & 4.89 & 2.67 & 7.25 & 7.43 & 4.86 & na & 12.34 & 5.11 & na & na & na \\
\hline Tunusia & 3.13 & 2.41 & 10.52 & 3.45 & 4.19 & 2.31 & 2.90 & 11.15 & na & 8.28 & 8.11 & 7.91 \\
\hline Zambia & 3.07 & 3.09 & 9.20 & 4.08 & 6.03 & 2.68 & 8.65 & 14.95 & 2.70 & 15.56 & 7.32 & 13.45 \\
\hline Zaire & 4.21 & 5.37 & 14.87 & 6.90 & 6.96 & 4.88 & 5.56 & 20.18 & na & 11.39 & 16.21 & 14.89 \\
\hline Zimba & 4.92 & 4.82 & 11.10 & 5.94 & 7.15 & 5.85 & 8.22 & 20.71 & 4.97 & 13.15 & 9.23 & 12.41 \\
\hline Mean & 4.10 & 4.83 & 7.99 & 9.51 & 10.68 & 5.38 & 8.28 & 15.69 & 7.33 & 16.45 & 12.73 & 13.51 \\
\hline Median & 3.93 & 4.86 & 8.36 & 7.41 & 7.24 & 5.01 & 8.65 & 15.26 & 6.26 & 15.25 & 12.77 & 13.89 \\
\hline Std. Dev. & 1.41 & 1.53 & 3.57 & 9.18 & 12.30 & 2.14 & 3.80 & 4.52 & 4.48 & 6.15 & 6.53 & 4.53 \\
\hline
\end{tabular}

$\sigma_{\mathrm{x}}$ is the percent standard deviation of the variable $\mathrm{x} . \mathrm{y}=$ aggregate output=ind+ser+agr= industrial activity (manufacturing+mining and quarrying + electricity+gas+water)+services+agriculture; agr=agriculture; ind=industrial activity (manufacturing+mining and quarrying +

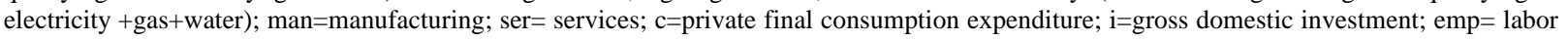
supply; $\mathrm{tb}=(\mathrm{exp}-\mathrm{imp}) / \mathrm{y}$; exp=exports; imp= imports. The data is in terms of real domestic prices, constructed for per capita quantities, logged and filtered using HP(100) filter. The data, for the period 1970-1992, comes from the World Bank World Tables (1994). See Appendix A2 for more information about the data. 
Table B2

Properties of Macroeconomic Fluctuations ${ }^{*}$

Persistence

\begin{tabular}{|c|c|c|c|c|c|c|c|c|c|c|c|}
\hline Country & $\rho_{y}$ & $\rho_{\text {agr }}$ & $\rho_{\text {ind }}$ & $\rho_{\operatorname{man}}$ & $\rho_{\text {ser }}$ & $\rho_{c}$ & $\rho_{\mathrm{i}}$ & $\rho_{\mathrm{emp}}$ & $\rho_{\mathrm{tb}}$ & $\rho_{\exp }$ & $\rho_{\text {imp }}$ \\
\hline Burundi & -0.47 & -0.41 & -0.35 & 0.09 & -0.12 & -0.30 & -0.14 & 0.10 & -0.06 & -0.22 & 0.14 \\
\hline Cape & 0.38 & 0.41 & 0.17 & 0.43 & 0.49 & 0.13 & 0.55 & na & 0.28 & 0.26 & 0.35 \\
\hline Egypt & 0.64 & 0.08 & 0.73 & na & 0.30 & 0.52 & 0.25 & 0.14 & 0.42 & 0.53 & 0.41 \\
\hline Gambia & -0.03 & 0.28 & 0.28 & 0.37 & -0.22 & 0.40 & -0.08 & 0.35 & 0.35 & 0.47 & 0.62 \\
\hline Ghana & 0.43 & 0.33 & 0.74 & 0.72 & 0.13 & 0.21 & 0.43 & 0.60 & -0.01 & 0.38 & 0.50 \\
\hline GuBis & 0.12 & 0.27 & 0.15 & 0.32 & -0.06 & 0.59 & na & na & 0.27 & 0.15 & 0.47 \\
\hline Kenya & 0.40 & 0.21 & 0.50 & 0.54 & 0.33 & 0.12 & 0.63 & 0.47 & 0.51 & 0.22 & 0.47 \\
\hline Liberia & 0.40 & 0.64 & 0.41 & 0.55 & 0.31 & 0.02 & na & na & 0.62 & 0.23 & 0.74 \\
\hline Mada & 0.27 & 0.23 & 0.56 & na & 0.30 & 0.27 & na & 0.33 & 0.29 & 0.46 & 0.39 \\
\hline Malavi & 0.26 & -0.26 & 0.39 & 0.32 & 0.20 & 0.10 & 0.52 & na & 0.14 & 0.06 & 0.14 \\
\hline Maurita & 0.05 & 0.08 & 0.20 & 0.49 & 0.44 & 0.34 & 0.32 & na & 0.61 & 0.23 & 0.18 \\
\hline Maurus & 0.62 & 0.14 & 0.73 & 0.58 & 0.77 & 0.63 & 0.73 & 0.77 & 0.61 & 0.41 & 0.82 \\
\hline Morocco & 0.06 & -0.04 & 0.48 & -0.10 & 0.34 & 0.29 & 0.54 & 0.06 & 0.56 & 0.18 & 0.67 \\
\hline Seychelles & 0.43 & -0.17 & -0.37 & 0.25 & 0.51 & 0.08 & 0.20 & na & 0.24 & 0.32 & -0.15 \\
\hline SLione & 0.60 & 0.55 & 0.23 & 0.44 & 0.57 & 0.57 & 0.03 & na & 0.45 & 0.28 & 0.56 \\
\hline Sudan & 0.50 & 0.12 & 0.44 & 0.44 & 0.63 & 0.49 & 0.41 & na & 0.34 & -0.04 & 0.50 \\
\hline Swazi & 0.56 & 0.05 & 0.60 & 0.59 & 0.56 & na & 0.44 & na & 0.60 & 0.55 & 0.48 \\
\hline Tanza & 0.76 & 0.32 & 0.53 & 0.67 & 0.65 & na & 0.09 & 0.51 & na & na & na \\
\hline Tunusia & 0.14 & 0.16 & 0.58 & 0.04 & 0.10 & 0.42 & 0.74 & na & 0.55 & 0.41 & 0.57 \\
\hline Zambia & 0.32 & 0.17 & 0.44 & 0.40 & 0.07 & 0.41 & 0.38 & 0.64 & 0.46 & 0.08 & 0.48 \\
\hline Zaire & 0.59 & 0.23 & 0.65 & 0.59 & 0.43 & 0.59 & -0.09 & na & -0.28 & 0.46 & 0.28 \\
\hline Zimba & 0.44 & -0.14 & 0.55 & 0.53 & 0.58 & 0.62 & 0.69 & 0.61 & 0.62 & 0.28 & 0.36 \\
\hline Mean & 0.34 & 0.15 & 0.39 & 0.41 & 0.33 & 0.32 & 0.35 & 0.42 & 0.36 & 0.27 & 0.43 \\
\hline Median & 0.40 & 0.16 & 0.46 & 0.44 & 0.33 & 0.37 & 0.41 & 0.47 & 0.42 & 0.28 & 0.47 \\
\hline Std. Dev. & 0.28 & 0.25 & 0.30 & 0.21 & 0.26 & 0.25 & 0.28 & 0.24 & 0.25 & 0.20 & 0.22 \\
\hline \multicolumn{12}{|c|}{$\begin{array}{l}{ }^{*} \text { is the first-order serial autocorrelation of the variable } \mathrm{x} . \mathrm{y}=\text { aggregate output=ind+ser+agr= industrial activity (manufacturing+mining and } \\
\text { quarrying }+ \text { electricity+gas+water)+services+agriculture; agr=agriculture; ind=industrial activity (manufacturing+mining and quarrying }+ \\
\text { electricity +gas+water); man=manufacturing; ser= services; } \mathrm{c}=\text { private final consumption expenditure; i=gross domestic investment; emp= labor } \\
\text { supply; tb=(exp-imp)/y; exp=exports; imp=imports. The data is in terms of real domestic prices, constructed for per capita quantities, logged } \\
\text { and filtered using HP(100) filter. The data, for the period } 1970-1992 \text {, comes from the World Bank World Tables (1994). See Appendix A2 for } \\
\text { more information about the data. }\end{array}$} \\
\hline
\end{tabular}




\section{Properties of Macroeconomic Fluctuations*}

Comovement

\begin{tabular}{|c|c|c|c|c|c|c|c|c|c|c|}
\hline Country & $\rho_{\text {agr,y }}$ & $\rho_{\text {ind,y }}$ & $\rho_{\text {man,y }}$ & $\rho_{\text {ser,y }}$ & $\rho_{c, y}$ & $\rho_{\mathbf{i}, \mathbf{y}}$ & $\rho_{\text {emp,y }}$ & $\rho_{\mathrm{tb}, \mathbf{y}}$ & $\rho_{\text {exp,y }}$ & $\rho_{\text {imp,y }}$ \\
\hline Burundi & 0.97 & 0.91 & 0.44 & 0.81 & 0.84 & -0.26 & -0.05 & 0.10 & 0.10 & -0.04 \\
\hline Cape & -0.18 & 0.53 & na & 0.59 & -0.32 & 0.44 & na & 0.60 & 0.60 & 0.17 \\
\hline Egypt & -0.13 & 0.77 & na & 0.60 & 0.43 & 0.51 & -0.02 & 0.27 & 0.39 & 0.03 \\
\hline Gambia & 0.77 & -0.21 & 0.18 & 0.59 & -0.26 & 0.16 & 0.44 & 0.26 & 0.32 & -0.03 \\
\hline Ghana & 0.93 & -0.04 & -0.32 & 0.76 & 0.74 & 0.26 & -0.40 & -0.29 & -0.35 & 0.15 \\
\hline GuBis & 0.33 & 0.23 & 0.88 & 0.82 & 0.18 & na & na & -0.17 & 0.25 & -0.02 \\
\hline Kenya & 0.86 & 0.93 & 0.92 & 0.94 & 0.81 & 0.74 & 0.72 & -0.25 & 0.05 & 0.23 \\
\hline Liberia & 0.60 & 0.71 & 0.76 & 0.50 & 0.13 & na & na & -0.12 & 0.40 & 0.62 \\
\hline Mada & 0.35 & 0.78 & na & 0.83 & 0.75 & na & -0.46 & -0.28 & 0.56 & 0.61 \\
\hline Malavi & 0.76 & 0.59 & 0.23 & 0.28 & 0.52 & 0.67 & 0.32 & -0.21 & 0.23 & 0.38 \\
\hline Maurita & 0.39 & 0.06 & 0.26 & 0.54 & -0.24 & 0.27 & na & 0.07 & 0.20 & -0.10 \\
\hline Maurus & 0.51 & 0.96 & 0.81 & 0.73 & 0.61 & 0.75 & 0.75 & -0.57 & 0.51 & 0.79 \\
\hline Morocco & 0.75 & 0.53 & 0.42 & 0.43 & 0.80 & 0.47 & 0.14 & -0.41 & -0.12 & 0.45 \\
\hline Seychelles & 0.15 & 0.55 & 0.63 & 0.88 & -0.52 & 0.75 & -0.38 & 0.50 & 0.67 & 0.11 \\
\hline SLione & -0.35 & 0.44 & 0.44 & 0.78 & 0.58 & 0.53 & na & -0.19 & -0.13 & 0.13 \\
\hline Sudan & 0.78 & 0.79 & 0.67 & 0.86 & 0.78 & 0.50 & na & -0.35 & 0.13 & 0.45 \\
\hline Swazi & 0.57 & 0.83 & 0.84 & 0.79 & na & 0.64 & 0.10 & -0.20 & 0.64 & -0.15 \\
\hline Tanza & 0.62 & 0.83 & 0.79 & 0.70 & na & 0.26 & 0.64 & na & na & na \\
\hline Tunusia & 0.77 & 0.78 & 0.75 & 0.70 & 0.60 & 0.51 & na & -0.03 & 0.36 & 0.40 \\
\hline Zambia & 0.44 & 0.93 & 0.83 & 0.84 & 0.34 & 0.47 & 0.43 & -0.24 & 0.25 & 0.41 \\
\hline Zaire & 0.64 & 0.94 & 0.81 & 0.95 & 0.84 & 0.30 & na & -0.36 & 0.42 & 0.69 \\
\hline Zimba & 0.65 & 0.71 & 0.89 & 0.79 & 0.22 & 0.81 & 0.87 & -0.17 & 0.57 & 0.61 \\
\hline Mean & 0.51 & 0.62 & 0.59 & 0.71 & 0.39 & 0.46 & 0.22 & -0.10 & 0.29 & 0.28 \\
\hline Median & 0.61 & 0.74 & 0.75 & 0.77 & 0.55 & 0.50 & 0.23 & -0.19 & 0.32 & 0.23 \\
\hline Std. Dev. & 0.36 & 0.33 & 0.33 & 0.17 & 0.43 & 0.26 & 0.45 & 0.30 & 0.27 & 0.28 \\
\hline \multicolumn{11}{|c|}{$\begin{array}{l}\rho_{x, y} \text { is the contemporaneous correlation between the variables } \mathrm{x} \text { and } \mathrm{y} . \mathrm{y}=\text { aggregate output=ind+ser+agr= industrial activity (manufacturing }+ \\
\text { mining and quarrying+electricity+gas+water)+services+agriculture; agr=agriculture; ind=industrial activity (manufacturing+mining and } \\
\text { quarrying + electricity +gas+water); man=manufacturing; ser= services; c=private final consumption expenditure; } i=\text { gross domestic investment } \\
\text { emp= labor supply; tb=(exp-imp)/y; exp=exports; imp=imports. The data is in terms of real domestic prices, constructed for per capita } \\
\text { quantities, logged and filtered using HP(100) filter. The data, for the period } 1970-1992 \text {, comes from the World Bank World Tables (1994). See } \\
\text { Appendix A2 for more information about the data. }\end{array}$} \\
\hline
\end{tabular}


